Santos et al. (2010) reported on the capture of a male bottlenose dolphin for public display at a small facility in São Vicente, São Paulo (SP) State, Brazil. The dolphin was captured in SC $\left(27^{\circ} \mathrm{S}\right)$ in 1983 and released into the wild in 1993 at the same spot in which it was captured (Santos et al., 2010). After released, the dolphin was sighted in the southern waters of the SP coast, Cananéia Estuary $\left(25^{\circ} \mathrm{S}\right)$ and Santos $\left(24^{\circ} \mathrm{S}\right)$, and it was last seen in Paraná (PR) State coastal waters $\left(26^{\circ} \mathrm{S}\right)$ in October 1994.

Dolphins in south and southeast Brazil are not seen as usual competitors for resources or rivals to humans, as are sea lions that depredate fishing nets and are victims of intentional killing by fishermen (Kalikoski, 2002; Zappes et al., 2011a, $b$; 2014). Instead, artisanal fishermen using hand cast nets have a feeling of respect and gratitude to bottlenose dolphins (e.g. Simóes-Lopes et al., 1998; Peterson et al., 2008; Zappes et al., 2011a). However, in Arraial do Cabo, Rio de Janeiro (RJ) State, Brazil, fishermen considered bottlenose and other coastal dwelling species of dolphins as potential competitors for fish. In this area, bottlenose dolphins were once common in the shoals ${ }^{1}$ (baixio de dentro) but no longer use the area. It is suggested that harassment by fishermen could have displaced the dolphins from there ${ }^{2}$.

In Argentina two dolphins were captured for scientific purposes early in the last century: a female in 1904 in Quilmes and a male in 1907 in Punta Lara, both in La Plata River (Lahille, 1908). Although it is plausible that wild dolphins have been captured in the past in Argentinean waters to be kept in captivity in the two delphinariums located in Argentina - Mundo Marino (MM) (since 1978) and Mar del Plata Aquarium (MPA) (since 1993) - this is in contradiction with the information that 10 of the 13 dolphins currently displayed at MM were born in captivity (Mundo Marino, unpub. data). According to MM directors, the three wild dolphins in MM were found stranded alive or entangled in fishing nets twenty years ago and translocated to MM. The first bottlenose dolphin born at Mundo Marino was in 1982, a female that is still at the park and has had a second-generation calf. Five of the animals at MM are secondgeneration individuals (Mundo Marino, unpub. data). For MPA, all dolphins were reportedly imported from Cuba. Published data from the international trade of bottlenose dolphins exported from that country between 1986 and 2004 corroborate the above information since Argentina is reported as the destination of six dolphins (three in 1996, two in 1998 and one in 2001) (Van Waerebeek et al., 2006).

\footnotetext{
${ }^{1}$ Gomes, L.A. (1986) Análise sobre a ocorrência de Tursiops truncatus na região de Arraial do Cabo (Rio de Janeiro, Brasil). Pages 122-131 in Castello, H.P. and Waiss, I.R. (Eds) Actas, Primera Reunión de Trabajo de Expertos en Mamíferos Acuáticos de América del Sur, 25-29 June 2004, Buenos Aires, Argentina.

${ }^{2}$ S. Siciliano, pers. comm., 21 May 2010
}

\section{Incidental captures}

Among many human activities known to threat the survival of cetaceans worldwide, incidental captures in fishing nets are likely the most significant (Reeves et al., 2003; Read et al., 2006). Substantial bycatch rates have been recorded since the early 1970s and they are still a critical global conservation issue deserving special attention (Reeves et al., 2013). Entanglements of cetaceans and other marine mammals have been reported for many species and regions along the SWAO. Gillnet fisheries seem to have the highest records of dolphin entanglements (e.g. Siciliano, 1994; Netto and Barbosa, 2003; Secchi, 2010). This type of fishery, used for both industrial and artisanal purposes, has increased in effort (increase in both net size and time in the water) in the last decades in the SWAO as a response to decreasing yield of fish stocks (e.g. Haimovici et al., 1997; Kalikoski et al., 2002; Delfino et al., 2003; Pin et al., 2003). The franciscana dolphin (Pontoporia blainvillei) is potentially the most impacted small coastal cetacean in the SWAO by the gillnet fishery (Secchi, 2010; 2014). Data from strandings and monitoring programs of fishing fleets suggest relatively lower levels of incidental mortality for bottlenose dolphins (see below; Tables 1 and 2).

\section{Northeast Brazil}

Information obtained from strandings indicate overall low mortality and bycatch rates of bottlenose dolphins in northeastern Brazil (Siciliano, 1994; Meirelles et al., 2016 this volume). From 72 strandings recorded between 1992 and 2010 along approximately $2437 \mathrm{~km}$ of the coast (between Ceará and Bahia states, excluding the coast of Sergipe), six dolphins $(8.3 \%)$ presented evidence of fishery interactions (Table 1).

\section{Southeast Brazil}

Bycatch data collected from several sources, which include systematic fishery fleet monitoring, beach surveys and occasional strandings, suggest low numbers of bottlenose dolphin entanglements $(n=18)$ along the coast of Espírito Santo (ES), RJ and SP states (Tables 1 and 2). A total of eight records of bycatch of bottlenose dolphins were found in the surveyed literature for systematic fisheries fleet monitoring programs conducted in southeast Brazil. Despite sporadic bycatch in pelagic driftnets, the majority ( $\mathrm{n}=7 ; 88.8 \%$ ) of the entanglements were assigned to gillnet fisheries in coastal areas, which routinely reported a series of incidental captures for other cetacean species (Table 2). No data on the sex and age of the bycaught bottlenose dolphins were available.

Interviews with artisanal fishermen operating in Cagarras Archipelago and adjacent waters in RJ, where a population of bottlenose dolphins has been studied since 2004 (Lodi et al., 2009), revealed the occurrence of incidental catches (Zappes et al., 2011b). Five (33.3\%) fishermen said that one bottlenose dolphin is caught in gillnets every year and by caught carcasses are discarded in the sea, used for bait in the long-line fishery, or occasionally for food consumption by their own families. 
Table 1. Summary of historical information on the bycatch of bottlenose dolphins (Tursiops truncatus) recorded from external examination of stranded individuals along the Southwest Atlantic Ocean. NA = information not available.

\begin{tabular}{|c|c|c|c|c|c|c|c|}
\hline Country & Region & Study area & $\begin{array}{l}\text { Study } \\
\text { period }\end{array}$ & Approach & $\begin{array}{l}\text { Strandings } \\
\text { (n) }\end{array}$ & $\begin{array}{l}\text { Bycatch } \\
\text { (n) }\end{array}$ & Source $(s)$ \\
\hline \multirow{8}{*}{ 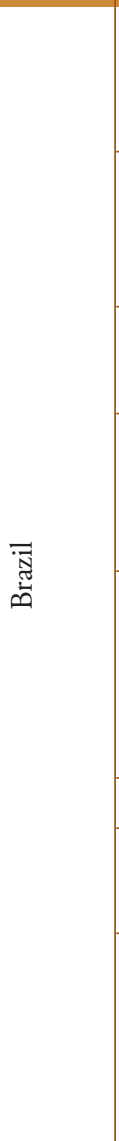 } & Northeast & $\begin{array}{c}\text { Ceará, Rio Grande do Norte, } \\
\text { Paraíba, Pernambuco, Alagoas } \\
\text { and Bahia States }\end{array}$ & $1992-2010$ & Non-systematic & 72 & 6 & $\begin{array}{l}\text { Siciliano (1994); } \\
\text { Meirelles et al. (2016 this } \\
\text { volume) }\end{array}$ \\
\hline & Southeast & $\begin{array}{c}\text { Atlantic coast of Espírito Santo } \\
\text { State }\end{array}$ & 1984-2001 & Non-systematic & NA & 1 & $\begin{array}{c}\text { Barros (1991); } \\
\text { Siciliano (1994); } \\
\text { Netto and Barbosa (2003) }\end{array}$ \\
\hline & Southeast & $\begin{array}{c}\text { Between Sáo Francisco de } \\
\text { Itabapoana and Saquarema, RJ }\end{array}$ & 1999-2009 & Beach surveys & 49 & 9 & $\begin{array}{c}\text { Moura et al. } \text { (2016 this } \\
\text { volume) }\end{array}$ \\
\hline & Southeast & $\begin{array}{c}\text { Between Saquarema and } \\
\text { Paraty, RJ }\end{array}$ & $1995-2015$ & Non-systematic & 25 & NA & $\begin{array}{c}\text { Lab. de Mamíferos } \\
\text { Aquáticos e Bioindicadores - } \\
\text { unpub. data }\end{array}$ \\
\hline & South & $\begin{array}{l}\text { Between Matinhos and } \\
\text { Superagüi, PR }\end{array}$ & $\begin{array}{l}1997-1999 \\
2007-2009\end{array}$ & $\begin{array}{c}\text { Non-systematic } \\
(1997-1999) ; \\
\text { Systematic } \\
(2007-2009)\end{array}$ & 18 & 1 & Domit et al. ${ }^{3}$ \\
\hline & South & Florianópolis, SC & 2009 & Opportunistic & 1 & 1 & Flores et al. ${ }^{4}$ \\
\hline & South & Along the coast of SC & $1940-1991$ & Opportunistic & 11 & 3 & $\begin{array}{c}\text { Simóes-Lopes and Ximenez } \\
\text { (1993) }\end{array}$ \\
\hline & South & $\begin{array}{c}\text { Between Lagoa do Peixe and } \\
\text { Barra do Chuí, RS }\end{array}$ & $1969-2006$ & $\begin{array}{c}\text { Non-systematic } \\
(1969-1982) ; \\
\text { Systematic } \\
(1983-2006)\end{array}$ & 188 & 36 & Fruet et al. (2012) \\
\hline \multirow{2}{*}{ 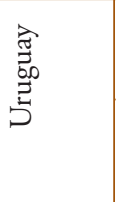 } & $\begin{array}{c}\text { La Plata } \\
\text { River }\end{array}$ & Punta Gorda & 1959 & Non-systematic & NA & 1 & $\begin{array}{c}\text { National Museum of } \\
\text { Natural History of Uruguay }\end{array}$ \\
\hline & $\begin{array}{l}\text { Atlantic } \\
\text { Ocean }\end{array}$ & La Coronilla & 1971 & Non-systematic & 0 & 1 & Pilleri and Gihr (1972) \\
\hline \multirow{2}{*}{ 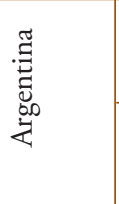 } & North & $\begin{array}{c}\text { Mar del Plata, Province of } \\
\text { Buenos Aires }\end{array}$ & 1984-1988 & Non-systematic & 1 & 0 & Bastida et al. ${ }^{5}$ \\
\hline & South & $\begin{array}{c}\text { Beaches of Tierra del Fuego, } \\
\text { Patagonia }\end{array}$ & $1975-2010$ & Non-systematic & 8 & NA & Goodall et al. (1989; 2011) \\
\hline
\end{tabular}

${ }^{3}$ Domit, C., Weber Rosas, F.C., Rosso-Londoño, M.C., Ougo, G., Bracarense, A.P.F.R., Domiciano, I.G., Beloto, N. and Monteiro-Filho, E.L.A. (2010) Ocorrência de Tursiops truncatus (Montagu, 1821) no litoral do estado do Paraná, no período de 1997/1999 e 2007/2009. Working Paper 15 presented during the First Workshop on the Research and Conservation of Tursiops truncatus: Integrating knowledge about the species in the Southwest Atlantic Ocean, $21-23$ May 2010, Rio Grande, RS, Brazil.

${ }^{4}$ Flores, P.A.C., Pretto, D.J. and Rocha, H.J.F. (2010) A note on a stranded bottlenose dolphin with intensive fishing gear. Working Paper 63 presented during the First Workshop on the Research and Conservation of Tursiops truncatus: Integrating knowledge about the species in the Southwest Atlantic Ocean, 21-23 May 2010, Rio Grande, RS, Brazil.

${ }^{5}$ Bastida, R., Rodríguez, D., Moreno, V., Pérez, A., Marcovecchio, J. and Gerpe, M. (1992) Varamientos de pequeños cetaceos durante el periodo $1984-1988$ en el area de Mar del Plata (Provincia de Buenos Aires, Argentina). Pages 1-12 in Anales, $3^{a}$ Reunión de Trabajo de Especialistas en Mamiferos Acuáticos de América del Sur, 25-30 July 1988, Montevideo, Uruguay. 
Table 2. Compiled information on fisheries and bycatch of bottlenose dolphins (Tursiops truncatus) collected during monitoring programs of fisheries along the Southwest Atlantic Ocean. Records of bycatch of other marine mammal species are also shown. SY= Systematic; NS= Non-systematic; NA= information not available; SC = Santa Catarina State; ES= Espírito Santo State; $\mathrm{RJ}=$ Rio de Janeiro State; $\mathrm{SP}=$ São Paulo State; PR=Paraná State; RS= Rio Grande do Sul State; UY = Uruguay; $\mathrm{AR}=$ Argentina; $\mathrm{RD}=$ Rocha Departament; $\mathrm{PBA}=$ Provincia de Buenos Aires.

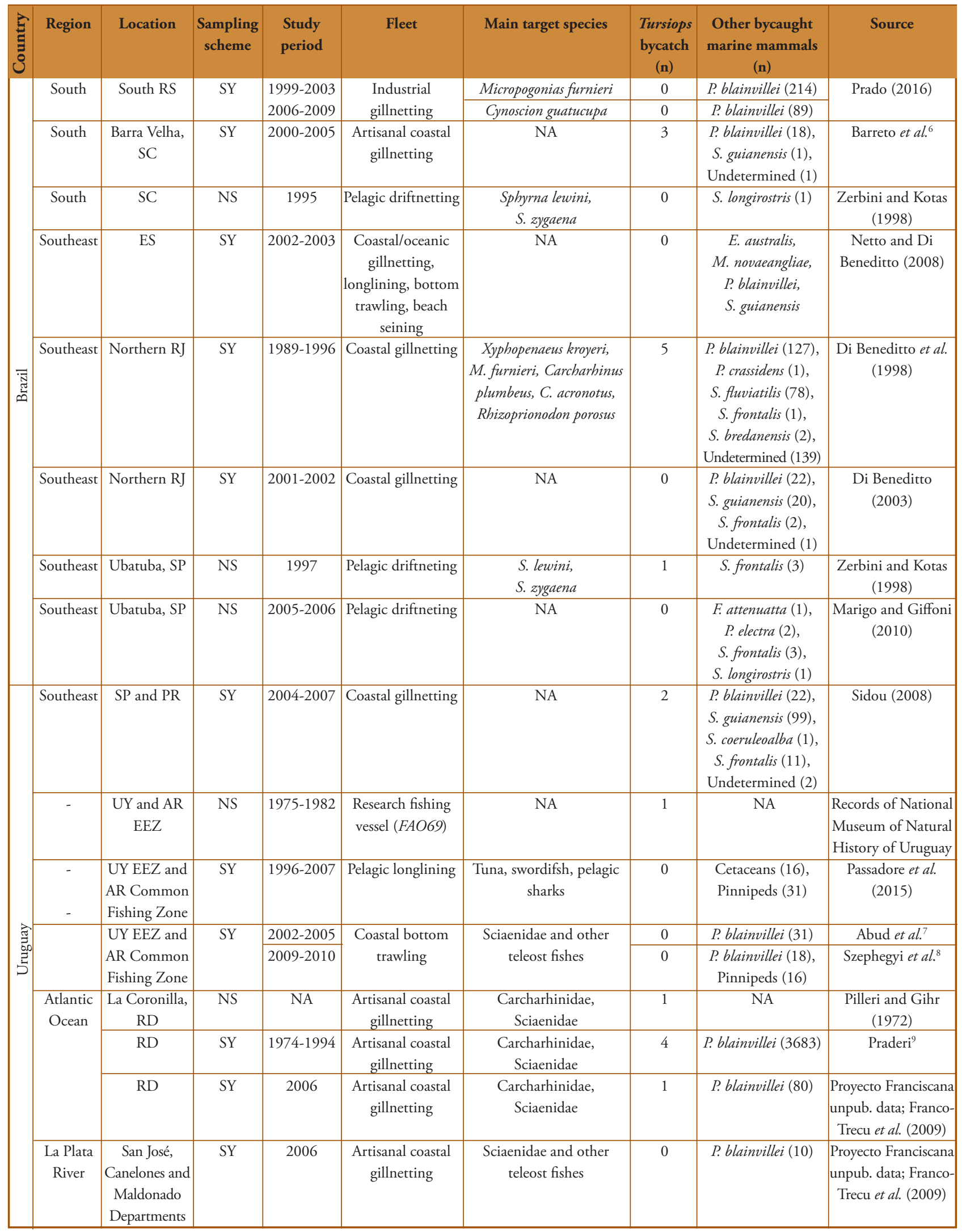




\begin{tabular}{|c|c|c|c|c|c|c|c|c|c|}
\hline$\stackrel{E}{E}$ & Region & Location & $\begin{array}{l}\text { Sampling } \\
\text { scheme }\end{array}$ & $\begin{array}{l}\text { Study } \\
\text { period }\end{array}$ & Fleet & Main target species & $\begin{array}{c}\text { Tursiops } \\
\text { bycatch } \\
\text { (n) }\end{array}$ & $\begin{array}{l}\text { Other bycaught } \\
\text { marine mammals } \\
\text { (n) }\end{array}$ & Source \\
\hline \multirow{12}{*}{ 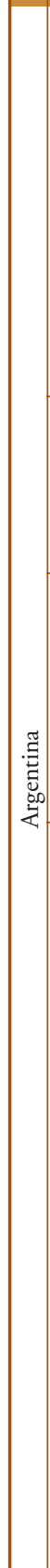 } & & Plata, PBA & & & gillnetting & & & P. blainvillei & Lichtschein $^{10}$ \\
\hline & & \multirow{2}{*}{$\begin{array}{l}\text { Nechochea } \\
\text { and } \\
\text { Claromecó } \\
\text { fishing } \\
\text { villages, PBA }\end{array}$} & SY & $1988-1990$ & $\begin{array}{l}\text { Artisanal coastal } \\
\text { gillnetting }\end{array}$ & $\begin{array}{c}\text { Sharks (Galeorhinus galeus, } \\
\text { Mustelus spp., Eugomphodus } \\
\text { taurus, Squatina argentina) }\end{array}$ & 0 & $\begin{array}{l}\text { D. delphis (1), } \\
\text { L. obscurus (2), } \\
\text { P. spinipinnis (6), } \\
\text { P. blainvillei (47) }\end{array}$ & \multirow[t]{2}{*}{$\begin{array}{l}\text { Corcuera et al. } \\
\quad(1994)\end{array}$} \\
\hline & & & NS & 1989 & Purse-seining & $\begin{array}{l}\text { Anchovies (Engraulis } \\
\text { anchoita), mackerel } \\
\text { (Scomber japonicus) }\end{array}$ & 0 & $\begin{array}{l}\text { D. delphis (32), } \\
\text { L. obscurus (64) }\end{array}$ & \\
\hline & & $\begin{array}{l}\text { Cabo San } \\
\text { Antonio, } \\
\text { PBA }\end{array}$ & SY & $1999-2000$ & $\begin{array}{l}\text { Artisanal coastal } \\
\text { gillnetting }\end{array}$ & $\begin{array}{c}\text { Sciaenidae and other } \\
\text { teleost fishes, small sharks }\end{array}$ & 0 & $\begin{array}{l}\text { P. spinipinnis (6), } \\
\text { P. blainvillei (52) }\end{array}$ & $\begin{array}{l}\text { Bordino et al. } \\
\quad(2002)\end{array}$ \\
\hline & North & $\begin{array}{c}\text { Bahía } \\
\text { Samborom- } \\
\text { bón to Mar } \\
\text { del Plata, } \\
\text { PBA }\end{array}$ & SY & $1988-1990$ & $\begin{array}{c}\text { Artisanal coastal } \\
\text { gillnetting and } \\
\text { bottom trawling }\end{array}$ & $\begin{array}{c}\text { Sciaenidae and other } \\
\text { teleost fishes, Argentine } \\
\text { hake (Merluccius hubbsi), } \\
\text { Argentine red shrimp } \\
\text { (Pleoticus muelleri) }\end{array}$ & NA & $\begin{array}{l}\text { D. delphis, } \\
\text { L. obscurus }\end{array}$ & Crespo et al. (1994) \\
\hline & $\begin{array}{c}\text { Central/ } \\
\text { South }\end{array}$ & $\begin{array}{l}\text { From Rio } \\
\text { Negro to } \\
\text { Tierra del } \\
\text { Fuego } \\
\text { Provinces, } \\
\text { Patagonia }\end{array}$ & & & Purse-seining & $\begin{array}{l}\text { Anchovies, mackerel } \\
\text { (Scomber japonicus) }\end{array}$ & 0 & $\begin{array}{l}\text { C. commersonii, } \\
\text { D. delphis, } \\
\text { G. melas, } \\
\text { L. australis, } \\
\text { O. flavescens, } \\
\text { P. dioptrica; } \\
\text { P. blainvillei }\end{array}$ & \\
\hline & \multirow[t]{6}{*}{$\begin{array}{l}\text { Central/ } \\
\text { South }\end{array}$} & \multirow[t]{3}{*}{$\begin{array}{l}\text { Along the } \\
\text { coast of } \\
\text { Patagonia }\end{array}$} & \multirow[t]{3}{*}{ SY } & \multirow[t]{3}{*}{ 1992-1994 } & $\begin{array}{l}\text { Mid-water } \\
\text { trawling }\end{array}$ & $\begin{array}{l}\text { Argentine hake, shortfin } \\
\text { squid (Illex argentinus), } \\
\text { Argentine red shrimp }\end{array}$ & 0 & $\begin{array}{c}97 \text { marine mammals: } \\
\text { C. commersonii, } \\
\text { L. obscurus, } \\
\text { O. flavescens }\end{array}$ & \multirow[t]{3}{*}{ Crespo et al. (1997) } \\
\hline & & & & & Jiggins & $\begin{array}{c}\text { Shortfin squid, black } \\
\text { squid (Martialia hyadesi) }\end{array}$ & 0 & NA & \\
\hline & & & & & Longlining & $\begin{array}{c}\text { Patagonian toothfish } \\
\text { (Dissostichus eleginoides), } \\
\text { pink cuskeel (Genypterus } \\
\text { blacodes), Argentine hake }\end{array}$ & 0 & NA & \\
\hline & & $\begin{array}{c}\text { Argentine } \\
\text { shelf } \\
\left(38^{\circ} \mathrm{S}-48^{\circ} \mathrm{S}\right) \\
\end{array}$ & SY & 1989-1999 & $\begin{array}{l}\text { Mid-water } \\
\text { trawling }\end{array}$ & $\begin{array}{c}\text { Argentine hake, Argentine } \\
\text { red shrimp }\end{array}$ & 1 & $\begin{array}{l}\text { D. delphis (100), } \\
\text { L. obscurus (21), } \\
\text { Other delphinids (4) }\end{array}$ & $\begin{array}{l}\text { Dans et al. (1997) } \\
\text { Crespo et al. (2000) }\end{array}$ \\
\hline & & $\begin{array}{l}\text { Chubut } \\
\text { Province }\end{array}$ & NS & NA & Pelagic net & Anchovies & 0 & NA & Crespo et al. (2008) \\
\hline & & $\begin{array}{c}\text { Santa Cruz } \\
\text { and Tierra } \\
\text { del Fuego } \\
\text { Provinces, } \\
\text { Patagonia }\end{array}$ & SY & 1975-1990 & $\begin{array}{l}\text { Artisanal coastal } \\
\text { gillnetting; crab } \\
\text { netting and } \\
\text { trapping }\end{array}$ & $\begin{array}{c}\text { Southern red king crab } \\
\text { (Lithodes santolla), } \\
\text { Patagonian blennie } \\
\text { (Eleginops maclovinus) and } \\
\text { hake (Merluccius sp.) }\end{array}$ & & $\begin{array}{l}\text { C. commersonii (313), } \\
\text { L. australis (20), } \\
\text { L. peronii (6), } \\
\text { P. dioptrica (34), } \\
\text { P. spinipinnis (4), } \\
\text { Pinnipeds (12) }\end{array}$ & $\begin{array}{l}\text { Goodall et al. } \\
\text { (1994) }\end{array}$ \\
\hline
\end{tabular}

${ }^{6}$ Barreto, A.S., Henrique-Garcia, J. and Moreira, P.P. (2005) Histórico de 5 anos do Programa Pescador Amigo do Golfinho nas Comunidades de BarraVelha, Penha e Balneário Camboriú, SC. Page 50 in Abstracts, IV Encontro sobre Conservação e Pesquisa de Mamiferos Aquáticos, 12-15 November, Itajaí, Brazil.

${ }^{7}$ Abud, C., Costa, P., Dimitriadis, C., Franco-Trecu, V., Laporta, P. and Piedra, M. (2006) Pesca de arrastre: un nuevo problema para la Franciscana Pontoporia blainvillei en Uruguay. Page 65 in Abstracts, XII Reunión de Trabajo de Especialistas en Mamíferos Acuáticos del América del Sur y Primera reunión Internacional sobre el estudio de mamiferos acuáticos SOMEMMA-SOLAMAC, 5-9 November, Merida, Mexico.

${ }^{8}$ Szephegyi, M.N., Franco-Trecu, V., Doño, F., Reyes, F., Forselledo, R. and Crespo, E.A. (2010) Primer relevamiento sistemático de captura incidental de mamíferos marinos en la flota de arrastre de fondo costero de Uruguay. Pages 148-151 in Anales, VII Workshop for Research Coordination and Conservation of Pontoporia blainvillei (Gervais \& d'Orbigny, 1844), 24-28 October, Florianópolis, Brazil.

${ }^{9}$ Praderi, R. (2000) Estado actual de la mortalidad de franciscana en las pesquerías artesanales de Uruguay. Pages 12-16 in Report of the $3^{\text {rd }}$ Workshop for Research Coordination and Conservation of the Franciscana Dolphin in the Southwestern Atlantic. UNEP/CMS, Bonn.

${ }^{10}$ Bastida, R. and Lichtschein, V. (1986) Capturas incidentales de pequeńos cetáceos en el área de Mar del Plata (Prov. de Bs. As., Arg.). Pages 14-22 in Actas, $1^{a}$ Reunión de Trabajo de Especialistas en Mamiferos Acuáticos de América del Sur, 25-29 June, Buenos Aires, Argentina. 


\section{South Brazil and Uruguay}

The artisanal fishing fleet off Barra Velha and surrounding areas (SC) were systematically monitored during five years and a total of three bottlenose dolphins were reported to being caught in fishing nets ${ }^{6}$. With the exception of the previously mentioned study, data on the mortality of bottlenose dolphins in south Brazil originated from the external examination of stranded carcasses $^{3}$ (Simóes-Lopes and Ximenez, 1993; Fruet et al., 2012). From a total of 218 records of stranded individuals along the coast of south Brazil (about $1250 \mathrm{~km}$ of coast), 41 (18.8\%) had clear evidence of being caught in fishing nets. Bycatch rates were relatively high in SC (33.3\%) and RS (19.1\%) states, and low in PR (5.5\%) (Table 1). These bycatch rates should be viewed with caution because the advanced state of decomposition of several carcasses makes the external examination for bycatch signs difficult. For example, when mortality data was restricted to freshly stranded carcasses, bycatch rates in RS increased to $43 \%$ (Fruet et al., 2012). It is important to notice that within the coast of RS numbers compiled came from data collected over its south coast ( $c a$ $355 \mathrm{~km}$ ), where systematic beach monitoring for marine mammals has been conducted for more than three decades (Pinedo and Polacheck, 1999; Fruet et al., 2012; Prado et al., 2013). Analysis of this long-term series of stranding data revealed a substantial increase in incidental mortality in areas close to the Patos Lagoon Estuary (PLE), raising concerns about the conservation status of the small resident population inhabiting the PLE (Fruet et al., 2012).

Bycatch of bottlenose dolphins in south Rio Grande do Sul, Brazil

Although bottlenose dolphins and fisheries potentially co-exist in the estuarine waters of the Patos Lagoon since the beginning of European colonization in the region $\left(18^{\text {th }}\right.$ century), bycatch was first documented in 1975 for an individual captured in a net used to catch mullet (Mugil sp.) (Laboratório de Ecologia e Conservação da Megafauna Marinha - Ecomega, unpub. data). This coincides with the introduction of monofilament line and the intensification of gillnet fisheries in south Brazil (Kalikoski, 2002). However, unlike the franciscana dolphin, which has been intensely captured in gillnets since 1980 (Secchi, 2010), for decades the mortality of bottlenose dolphins due to interactions with fishing activities was sporadic (Fruet et al., 2012). A comprehensive analysis of stranding data over several decades revealed low bycatch rates of bottlenose dolphins during a period of 30 years (1969-1999), followed by a marked increase after 2001 (Fruet et al., 2012). During 20022006, the minimum number of bycaught dolphins per year in coastal areas close to the PLE varied from two to nine, and bycatch was responsible for at least $43 \%$ of the overall recorded mortality (Fruet et al., 2012). During this time, incidental captures were skewed toward males (3.5M:1F), which were predominantly $(57.1 \%)$ composed of immature animals (Fruet et al., 2012). Catches were strongly seasonal, occurring mostly during summer months (Fruet et al., 2012), when the gillnet fishery efforts are intensified in the estuarine and adjacent marine system (Di Tullio et al., 2015).

Changes in fishery areas and effort are suspected to be the most likely causes of increased bycatch in coastal areas close to the estuary (Di Tullio et al., 2015). The size of gillnets used by artisanal fisheries in the PLE and the time in the water have increased over time in response to the decreasing yield (Kalikoski, 2002). Today, nets could be $2000 \mathrm{~m}$ long, while initially they were about 50 to $300 \mathrm{~m}$ (Von Ihering, 1885). The artisanal fishery inside the Patos Lagoon has experienced a collapse in production due to overfishing and to non-selective fishing gear (Reis, 1992), resulting in loss of biodiversity, poverty and loss of cultural identity of fisheries communities, and therefore the fishery is going through a tragedy of the commons (Kalikoski et al., 2002). This made artisanal fishermen to start placing their nets in other areas inside the Lagoon and in adjacent coastal areas (Kalikoski $e t$ al., 2002), where bottlenose dolphins concentrate (Di Tullio et al., 2015).

Specific data from fisheries (e.g. target species, net mesh size, depth and location of fisheries) harming bottlenose dolphins in the PLE and adjacent coastal areas are still scarce. One isolated event of five dolphins supposedly killed in a net set for sharks in 1983 was reported, but no further information was provided $^{11}$. Records of free-swimming dolphins with pieces of net entangled on their back ${ }^{12}$ and carcasses washed ashore entangled in set nets (Figure 1) suggest that fisheries targeting demersal fishes, such as Atlantic white croaker (Micropogonias furnieri) and southern king croaker (Menticirrhus sp.) are the main sources of incidental dolphin mortality. The main types of fishing gears used by artisanal fishermen inside the PLE are gillnets, stow nets, bag nets and otter trawls (Kalikoski et al., 2002). Bottom gillnet fisheries for white croaker inside the lagoon generally occur in deeper waters (between $10-18 \mathrm{~m}$ ) than in coastal areas. Coastal zones are also subject to a type of fishery known as pesca de cabo (fishing cable). Fishermen use trammel gillnets, locally known as feiticeiras, which are composed of three overlapping rectangular panels constructed of nylon monofilament, with mesh size varying (between $3-12 \mathrm{~cm}$ ) according to the target fish species (Klippel et al., 2005). Nets are generally between $30-400 \mathrm{~m}$ in length and 1.5 to $2.2 \mathrm{~m}$ tall. The net is attached at one end by a cable, which is attached to a stake on the beach, while the other end is fixed to the sea bottom, staying in a perpendicular position in relation to the shore. It operates

\footnotetext{
${ }^{11}$ Pinedo, M.C. (1986) Mortalidade de Pontoporia blainvillei, Tursiops gephyreus, Otaria flavescens e Arctocephalus australis na costa do Rio Grande do Sul, Brasil, 1976-1983. Pages 187-199 in Actas, $1^{a}$ Reunión de Trabajo de Expertos en Mamíferos Acuáticos de América del Sur, 24-29 June, Buenos Aires, Argentina.

${ }^{12}$ Fruet, P.F., Hassel, L.B. and Di Tullio, J.C. (2004) Registro do boto, Tursiops truncatus, emalhado vivo em rede de pesca no Estuário da Lagoa dos Patos, RS, Brasil. Page 234 in Abstracts, XIV Congresso Brasileiro de Oceanografia, 10-15 October, Itajaí, SC, Brazil.
} 


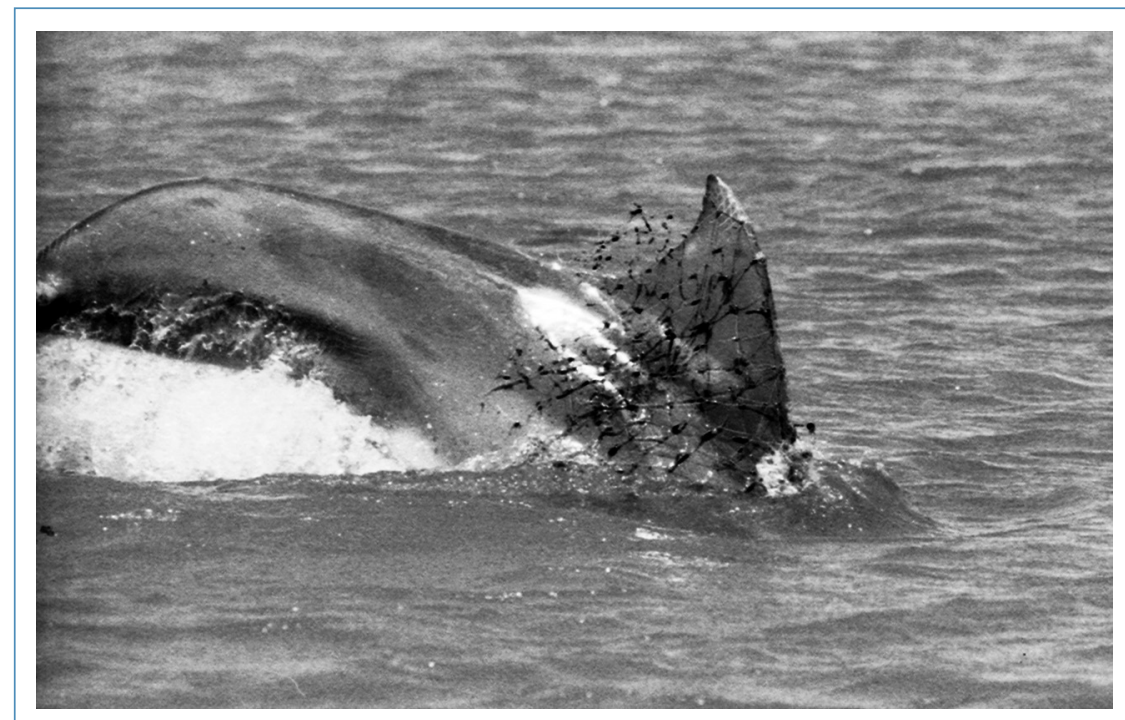

Figure 1. Examples of bottlenose dolphins entangled in fishing nets in southern Brazil. Left $=$ resident dolphin swimming in the Patos Lagoon Estuary with a piece of net used for catching Micropogonias furnieri entangled around its body; Below $=$ a stranded bottlenose dolphin completelly entangled in a net used by artisanal fishermen to catch Menticirrhus spp. in the first $400 \mathrm{~m}$ from the coastline.

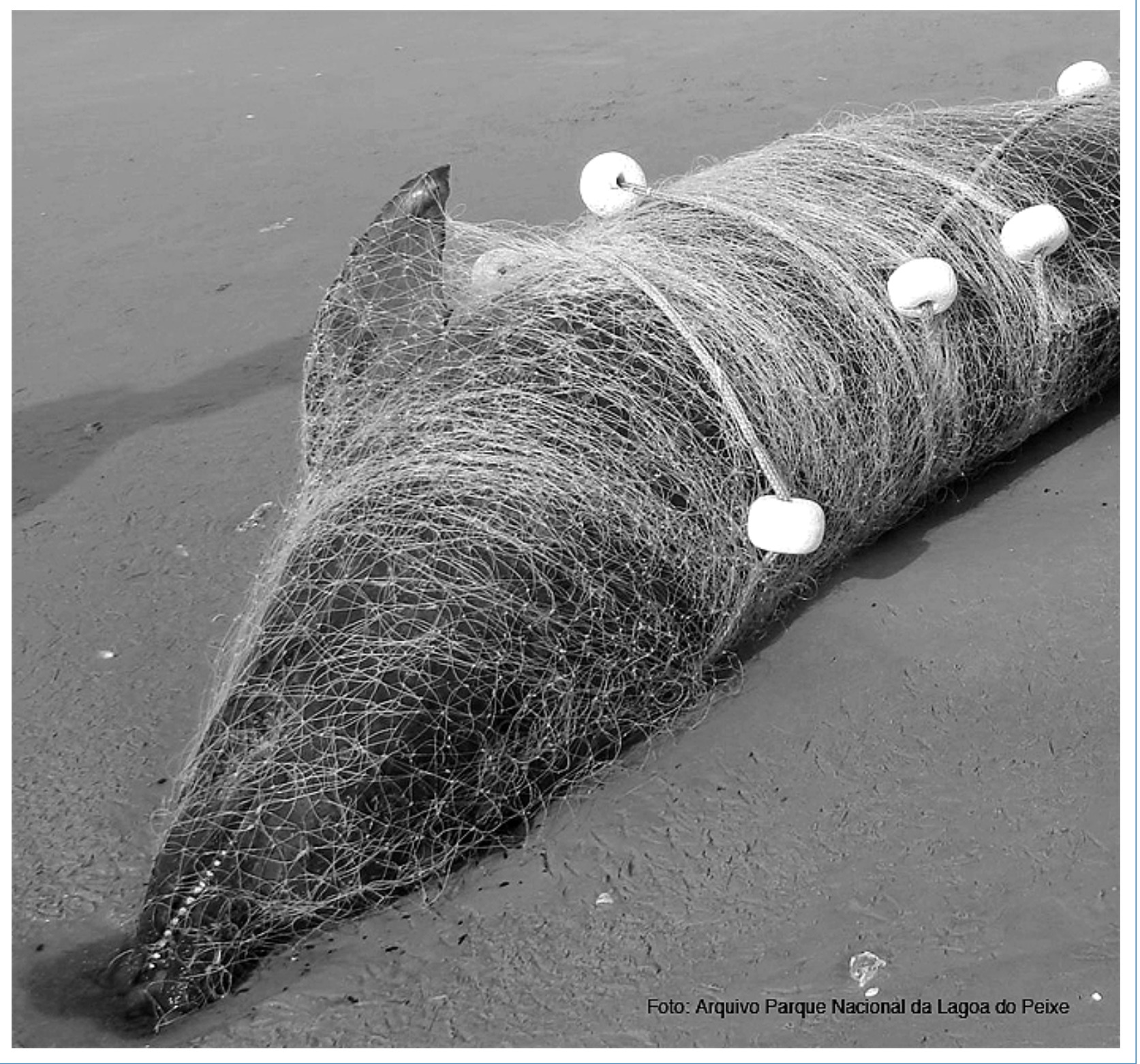


in very shallow waters (maximum depth of $8 \mathrm{~m}$ ) and can be placed up to $1 \mathrm{~km}$ away from the beach, greatly overlapping with the coastal distribution of bottlenose dolphins in this region (Di Tullio et al., 2015).

\section{Uruguay}

Incidental captures of bottlenose dolphins in Uruguayan fisheries seem to be occasional. Ricardo Praderi made the earliest record of a bottlenose dolphin incidentally captured in October 1959, concerning one individual captured in a fishing net in Punta Gorda, Montevideo (records in the National Museum of Natural History). After that only a few studies have reported the mortality of bottlenose dolphins in fishery activities, even in the face of systematic studies. For example, in a study about incidental captures of franciscana dolphins in the Atlantic Uruguayan coast, four specimens of bottlenose dolphins captured in artisanal fishing nets were reported over a period of 25 years (Praderi, 1985). In a similar study conducted between 2004 and 2006 along the estuarine and Atlantic Uruguayan coasts (Franco-Trecu et al., 2009), two bottlenose dolphins were reported by fishermen (Proyecto Franciscana, unpub. data). Past and present studies have surveyed the fleet of several fisheries in Uruguay, which include the pelagic longline (Passadore et al., 2015), coastal bottom trawl $1^{7,8}$ (Domingo et al., 2006; Laporta et al., 2006) and artisanal gillnet fishery9 (e.g. Franco-Trecu et al., 2009), but bycatch of bottlenose dolphins was recorded exclusively in coastal gillnets (Table 2).

The low number of bottlenose dolphins captured in Uruguayan waters could be explained by the differential spatial use between the species and the fisheries. The artisanal fishery of Uruguay operates between 0.3 and $28 \mathrm{~km}$ from the coast, depending on vessel length and capacity, but the greatest fishing effort occurs between 11 and $18 \mathrm{~km}$ from the coast $^{13}$ (Franco-Trecu et al., 2009; Zappes et al., 2014). This generates little overlap between coastal bottlenose dolphins and preferred fishing grounds, as dolphin sightings mainly occur within $0.5 \mathrm{~km}$ from the coast ${ }^{14}$ (Laporta, 2009; Zappes et al., 2014).

\section{Argentina}

According to the available literature, bottlenose dolphins do not interact regularly with fisheries in Argentinean waters. There is one past record of a male captured in the coastal fleet in Mar del Plata ${ }^{10}$ and one in the trawl fishery (Goodall et al., 1988). More recently, the bycatch of one bottlenose dolphin was recorded for the pelagic anchovy fishery along the Patagonian coast. This event occurred in the Anchovy

\footnotetext{
${ }^{13}$ Praderi, R. (1997) Análisis comparativo de estadísticas de captura y mortalidad incidental de Pontoporia blainvillei en Uruguay durante 20 ańos. Pages 42-53 in Pinedo, M.C. and Barreto, A.S. (Eds) Anais, $2^{\circ}$ Encontro sobre Coordenação de Pesquisa e Manejo da Franciscana, 22-23 October, Florianópolis, Brazil.

${ }^{14}$ Laporta, P., Di Tullio, J.C. and Secchi, E.R. (2010) Uso do habitat do boto Tursiops truncatus na costa atlântica uruguaia. Working Paper 65 presented during the First Workshop on the Research and Conservation of Tursiops truncatus: Integrating knowledge about the species in the Southwest Atlantic Ocean, 21-23 May 2010, Rio Grande, RS, Brazil.
}

Experimental Fishing Plan in the Province of Chubut (Crespo et al., 2008).

Since the mid 1980s several studies have monitored the fishing fleet operating around Argentinean waters in relation to marine mammal interactions (e.g. Pérez Macri and Crespo, 1989; Corcuera et al., 1994; Goodall et al., 1994; Crespo et al., 2000). These include fishing activities in the province of Buenos Aires (bottom trawling, purse-seining and gillnetting with bottom set nylon monofilament), Atlantic Patagonian coast (high sea fisheries: trawling, jiggins and longline), and Argentine shelf (mid-water trawl fishery). No catch of bottlenose dolphins was recorded during all these studies, although several other coastal and oceanic cetacean species were incidentally captured (Corcuera et al., 1994; Crespo et al., 1997; Crespo et al., 2000; Bordino et al., 2002) (Table 2).

\section{Caveats}

The findings reported here should be viewed with caution because the lack of systematic sampling in some regions (i.e. consistent beach or fishing fleet monitoring) make unclear if bycatch is low or if it is a result of poor sampling. This could lead to the initial conclusion that incidental captures are not a source of conservation concern for bottlenose dolphins along the SWAO. The incidental captures listed here are those known to have occurred, and an unknown, higher level of incidental captures is likely. Stranding carcasses were generally sampled in an advanced state of decomposition ${ }^{3}$ (Fruet et al., 2012) making it difficult to verify if a fishery interaction had occurred and this certainly underestimates bycatch rates. The low bycatch number reported should not be used as justification for neglecting the impacts of bycatch on bottlenose dolphins, as even a small number of incidental captures can pose a serious conservation threat for the small populations of coastal bottlenose dolphins in south Brazil, Uruguay and Argentina (Fruet et al., 2014; 2016 this volume).

\section{Bioaccumulation of pollutants}

Some micropollutants (e.g. heavy metals, polychlorinated biphenyls and chlorinated pesticides) biomagnify through food chains, reaching high concentration in top-order predators, such as marine mammals (Gray, 2002; Lailson-Brito et al., 2010; 2012; Bisi et al., 2011). Limited information has been published on contamination levels for the genus Tursiops in the SWAO. Currently, there is information on micropollutant contamination in bottlenose dolphins only for southeast and south Brazil and for the Argentinean coast (e.g. Marcovecchio et al., 1994; Dorneles et al., 2010; Lailson-Brito et al., 2012).

\section{Heavy metals \\ Southeast Brazil}

Renal cadmium concentrations were assessed in two bottlenose dolphins stranded on the coast of RJ (Dorneles et al., 2007; Table 3). Concentrations were low when compared with oceanic cetacean species but of similar magnitude to other coastal dolphins (Dorneles et al., 2007). The authors 
Table 3. Metal concentrations ( $\mu \mathrm{g} / \mathrm{g}$ wet weight) in tissues of bottlenose dolphins (Tursiops truncatus) from the Southwest Atlantic Ocean. Mean \pm standard deviation; range of concentrations (minimum-maximum); $\mathrm{n}=$ number of samples; blank cells = not analyzed; $\mathrm{DL}=$ detection limit $\mathrm{Cd}=$ cadmium; $\mathrm{Sn}=$ tin; $\mathrm{THg}=$ total mercury; $\mathrm{Zn}=$ zinc; $\mathrm{Cu}=$ copper.

\begin{tabular}{|c|c|c|c|c|c|c|c|c|}
\hline Locality & n & Tissue & Cd & Sn & THg & $\mathrm{Zn}$ & $\mathrm{Cu}$ & Source \\
\hline $\begin{array}{c}\text { Rio de Janeiro, } \\
\text { Brazil }\end{array}$ & 2 & liver & $\begin{array}{c}1.10 \pm 0.9 \\
(0.15-2.04)\end{array}$ & & & & & Dorneles et al. (2007) \\
\hline $\begin{array}{c}\text { Rio de Janeiro, } \\
\text { Brazil }\end{array}$ & 3 & liver & & $\begin{array}{c}2.58 \pm 0.5 \\
(<\mathrm{DL}-2.92)\end{array}$ & & & & Dorneles et al. (2008) \\
\hline \multirow{8}{*}{$\begin{array}{l}\text { Mar del Plata, } \\
\text { Argentina }\end{array}$} & \multirow[t]{8}{*}{1} & liver & & & 54.0 & & & \multirow[t]{8}{*}{ Moreno et al. (1984) } \\
\hline & & muscle & & & 3.2 & & & \\
\hline & & kidney & & & 8.3 & & & \\
\hline & & blubber & & & 0.4 & & & \\
\hline & & melon & & & 0.6 & & & \\
\hline & & lung & & & 1.6 & & & \\
\hline & & heart & & & 2.0 & & & \\
\hline & & brain & & & 0.7 & & & \\
\hline \multirow{6}{*}{$\begin{array}{c}\text { Mar del Plata, } \\
\text { Argentina }\end{array}$} & \multirow[t]{6}{*}{2} & liver & $0.8 \pm 0.2$ & & $86.0 \pm 7.3$ & $196 \pm 34.1$ & $77.7 \pm 3.8$ & \multirow{6}{*}{$\begin{array}{c}\text { Marcovecchio et al. } \\
\text { (1990) }\end{array}$} \\
\hline & & muscle & & & $5.50 \pm 0.8$ & $93.3 \pm 13.1$ & $6.3 \pm 1.1$ & \\
\hline & & kidney & $28.4 \pm 4.3$ & & $13.4 \pm 2.5$ & $93.6 \pm 5.9$ & $29.5 \pm 3.9$ & \\
\hline & & blubber & & & & $4.7 \pm 0.8$ & $4.0 \pm 0.6$ & \\
\hline & & melon & & & & $3.2 \pm 0.6$ & $2.7 \pm 0.4$ & \\
\hline & & $\begin{array}{l}\text { stomach } \\
\text { content }\end{array}$ & & & & & $1.2 \pm 0.2$ & \\
\hline
\end{tabular}

discussed that the cadmium concentrations observed may be related to predation on particular cephalopod species. As described for other regions, it was expected that oceanic dolphins in southeast Brazil prey on oceanic ommastrephid squids, which are well known for their high cadmium concentrations (Bustamante et al., 1998; Dorneles et al., 2007). On the other hand, inshore bottlenose dolphins probably feed on coastal loliginid cephalopods in which cadmium concentration is lower (Bustamante et al., 1998; Dorneles et al., 2007). Therefore, the cadmium trophic transfer to bottlenose dolphins is likely to be reduced in the latter (Dorneles et al., 2007).

A high hepatic total tin concentration was found in three bottlenose dolphins off the RJ coast (Dorneles et al. 2008a), indicating they were exposed to organotin compounds (Table 3). The mean total tin concentration was considered low only when compared to the Guiana dolphin (Sotalia guianensis) from Guanabara Bay (RJ), which is a highly polluted environment (Kjerfve et al., 1997; Dorneles et al., 2007; $2008 a, b$; Lailson-Brito et al., 2010). Organotin compounds have been widely used as antifouling agents in boats and they undergo bioaccumulation through food chains, reaching high concentrations in top predators (Tanabe, 1999).

\section{Argentina}

Moreno et al. (1984) assessed the total mercury concentration in 17 different tissues of one bottlenose dolphin incidentally captured in waters adjacent to the city of Mar del Plata. Concentrations ranged from 0.4 to $54 \mathrm{mg} / \mathrm{kg}$ (Table 3). High mean total mercury concentrations were found in the liver $(54 \mathrm{mg} / \mathrm{kg})$ and in the kidney $(8.3 \mathrm{mg} / \mathrm{kg})$. The levels were considered high and the authors attributed these findings to natural sources of mercury, but also to contributions from atmospheric sources (Moreno et al., 1984).

Marcovecchio et al. (1990; 1994) assessed tissue distribution of heavy metal concentration (total mercury, cadmium, zinc and copper) in two specimens of bottlenose dolphins stranded in beaches near Mar del Plata (Table 3). The authors found total mercury concentrations higher than in oceanic cetacean species, but the levels were lower when compared to cetacean 
species inhabiting highly contaminated areas (Marcovecchio et al., 1990; 1994). The tissue distribution concentration for total mercury, zinc and copper was similar to other studies of marine mammals from the South Atlantic coast, where these metals mostly concentrate in the liver followed by kidney and muscle (Das et al., 2003; Capelli et al., 2008). On the other hand, kidney was the most important accumulator organ for cadmium (Marcovecchio et al., 1990; 1994) due to the presence of metal-binding proteins in this tissue (Das et al., 2003).

\section{Organohalogen compounds \\ Southeast and southern Brazil}

Levels of dichloro diphenyl trichloroethane (DDT), polychlorinated biphenyls (PCBs) and hexachloro cyclo hexane $(\mathrm{HCH})$ were assessed in a male bottlenose dolphin stranded on the coast of SP (Yogui et al., 2010) (Table 4). The higher $\sum$ PCB than $\sum$ DDT concentration was attributed to the fact that the specimen was collected in an area under strong influence of pollutant discharge close to the city of Santos (Yogui et al., 2010).

Lailson-Brito et al. (2012) investigated organochlorine compound levels (PCBs, DDTs and HCB) in blubber samples of six delphinid species from RJ, including two specimens of bottlenose dolphins (Table 4). The authors found intermediate $\Sigma$ PCB and $\sum$ DDT levels for the species when compared to other delphinids. Mean $\Sigma$ PCB concentration was $11.8 \mu \mathrm{g} / \mathrm{g}$. Similar to the other species examined in that study, bottlenose dolphins presented a predominance of heavier PCBs, such as hexa-chlorobiphenyls and heptachlorobiphenyl. The predominant congeners were PCB 153, followed by PCB 138 and PCB 180 (Lailson-Brito et al., 2012). Bottlenose dolphins showed a mean $\sum \mathrm{DDT} / \Sigma \mathrm{PCB}$ ratio of 0.44 , which demonstrates that the species is predominantly exposed to compounds of industrial origin.

A study of organochlorine compounds contamination in the bubbler of bottlenose dolphins stranded in beaches from ES, RJ, PR and SC revealed a higher concentration in the specimen from ES, with the exception of $\mathrm{KHCH} 15$ (Table 4). PCBs showed the highest concentration in ES, RJ and SC, while in PR the highest concentration was observed for DDT (Table 4). The highest mean value of the $\sum \mathrm{DDT} / \sum \mathrm{PCB}$ ratio was observed in specimens from PR (1.55), while the lowest value occurred in individuals from ES (0.26). Samples from SC and RJ showed a ratio of 0.63 and 0.33 , respectively. These findings indicate that the main source of contamination in ES, $\mathrm{RJ}$ and $\mathrm{SC}$ was industrial. In PR, contributions from agricultural sources were more evident. The lower p,p'-DDE/ $/ D D T$ s ratio observed in bottlenose dolphins from $\mathrm{PR}$ indicate a recent discharge of DDT in the environment ${ }^{15}$ (Aguilar et al., 1999).

Contamination by organochlorine compounds (PCBs and DDTs) was measured in skin and blubber of 18 resident bottlenose dolphins from the PLE (RS) (Lago, 2006; Table 4). The highest mean concentration was found for $\Sigma \mathrm{PCB}$, but it was lower than values reported for bottlenose dolphins from the Northern Hemisphere (Morris et al., 1989; Corsolini et al., 1995; Hansen et al., 2004). Mean value of $\mathrm{p}, \mathrm{p}$-DDE/ $\sum \mathrm{DDT}$ ratio was 2.8 , indicating that DDT usage in the PLE is not recent (Lago, 2006). The levels of other chlorinated pesticides (e.g. chlordane, $\mathrm{HCH}$ and dieldrin) varied from below detection limit to $0.11 \mu \mathrm{g} / \mathrm{g}$. Overall, organochlorine compounds levels in bottlenose dolphins from the PLE were lower than those observed in the literature for this species (Lago, 2006). Dorneles et al. (2008b) evaluated the link between marine mammal exposure to perfluorooctane sulfonate (PFOs) and carbon stable isotope ratios $\left(\delta^{13} \mathrm{C}\right)$ in neritic and oceanic waters off Brazil. Carbon stable isotopes have been successfully used to trace the potential primary sources of food webs, indicating inshore versus offshore, or benthic versus pelagic contributions to food intake (McConnaughy and McRoy, 1979; Michener and Kaufman, 2007). The authors found a mean hepatic PFOs concentrations ranging from 63 to $91 \mathrm{ng} / \mathrm{g}$ in bottlenose dolphins (mean value $=74 \mathrm{ng} / \mathrm{g}$ ). Besides, a significant positive correlation between PFOs concentrations and $\delta^{13} \mathrm{C}$ value was verified (Dorneles et al., 2008b). These findings indicated that species, such as the bottlenose dolphin, that inhabit the continental shelf in highly industrialized areas were exposed to high concentrations of PFOs due to their proximity to effluent discharges (Dorneles et al., 2008b). The study suggests that organohalogen compounds may be exported to the continental shelf from Guanabara Bay, RJ (Dorneles et al., 2008b).

Dorneles et al. (2010) assessed hepatic concentration of anthropogenic (PBDEs) and naturally-produced (MeOPBDEs) organobrominated compounds in cetaceans from RJ, including three specimens of bottlenose dolphin. The mean PBDEs concentration was $957 \mathrm{ng} / \mathrm{g}$, and the results varied from 270 to $1353 \mathrm{ng} / \mathrm{g}$. The values found for eight congeners of PBDEs analyzed (Dorneles et al., 2010) were similar to that reported for harbour porpoises (Phocoena phocoena) from the North Sea (Covaci et al., 2002). However, the concentrations of naturally produced organobrominated compounds obtained for cetaceans from the RJ coast (minmax: 12458-32436ng/g for bottlenose dolphins) were among the highest reported for marine mammals worldwide (Dorneles et al., 2010).

\section{Habitat modification}

Human interferences to coastal ecosystems (particularly habitat modification, pollutants, overfishing and the introduction of invasive species) are known to have caused

\footnotetext{
${ }^{15}$ Vidal, L.G., Pinheiro, L.S., Ferraz, D.R., Cremer, M.J., Barbosa L.A., Domit, C., Azevedo, A.F. and Lailson-Brito, J. (2010) Compostos organoclorados (DDT, PCB, HCB, HCH e MIREX) em Tursiops truncatus da costa sudeste e sul do Brasil. Page 130, abstract 3054 in Abstracts, XIV Reunião de Trabalhos de Especialistas em Mamíferos Aquáticos da América do Sul, 20-24 October 2010, Florianópolis, Brazil.
} 
Table 4. Organochlorine concentrations ( $\sum \mathrm{PCB}, \sum \mathrm{DDT}, \mathrm{HCH}$, Mirex and HCB; $\mu \mathrm{g} / \mathrm{g}$ on a lipid basis) in the blubber of bottlenose dolphins (Tursiops truncatus) from the Southwest Atlantic Ocean. Mean \pm standard deviation; range of concentrations (minimum-maximum); $\mathrm{n}=$ number of samples; blank cells = not analyzed; $\mathrm{DL}=$ detection limit.

\begin{tabular}{|c|c|c|c|c|c|c|c|}
\hline Region & n & $\Sigma \mathrm{PCB}$ & $\sum \mathrm{DDT}$ & $\Sigma \mathrm{HCH}$ & Mirex & HCB & Reference \\
\hline $\begin{array}{c}\text { Espírito Santo, } \\
\text { Brazil }\end{array}$ & 2 & $52.9 \pm 51.8$ & $13.5 \pm 12.5$ & $0.79 \pm 0.51$ & $1.51 \pm 1.32$ & $0.004 \pm 0.004$ & Vidal et al. ${ }^{15}$ \\
\hline $\begin{array}{c}\text { Rio de Janeiro, } \\
\text { Brazil }\end{array}$ & 5 & $20.3 \pm 14.7$ & $7.42 \pm 5.88$ & $0.32 \pm 0.27$ & $0.53 \pm 0.42$ & $0.02 \pm 0.02$ & Vidal et al. ${ }^{15}$ \\
\hline $\begin{array}{c}\text { Rio de Janeiro, } \\
\text { Brazil }\end{array}$ & 2 & $\begin{array}{c}11.8 \pm 2.4 \\
(10.1-13.5)\end{array}$ & $\begin{array}{c}5.0 \pm 0.6 \\
(4.55-5.47)\end{array}$ & & & $\begin{array}{l}0.05 \pm 0.02 \\
(0.04-0.07)\end{array}$ & $\begin{array}{l}\text { Lailson-Brito et al. } \\
\qquad(2012)\end{array}$ \\
\hline $\begin{array}{l}\text { São Paulo, } \\
\text { Brazil }\end{array}$ & 1 & 5.91 & 2.42 & 0.01 & 0.09 & 0.08 & Yogui et al. (2010) \\
\hline $\begin{array}{c}\text { Paraná, } \\
\text { Brazil }\end{array}$ & 2 & $6.67 \pm 3.13$ & $10.4 \pm 11.9$ & $1.09 \pm 0.90$ & $0.59 \pm 0.65$ & $<\mathrm{DL}$ & Vidal et al. ${ }^{15}$ \\
\hline $\begin{array}{c}\text { Santa Catarina, } \\
\text { Brazil }\end{array}$ & 3 & $5.72 \pm 3.05$ & $3.59 \pm 1.72$ & $0.29 \pm 0.12$ & $0.24 \pm 0.08$ & $0.01 \pm 0.01$ & Vidal et al. ${ }^{15}$ \\
\hline $\begin{array}{c}\text { Rio Grande do Sul, } \\
\text { Brazil }\end{array}$ & 18 & $\begin{array}{l}26.2 \pm 12.6 \\
(7.89-46.2)\end{array}$ & $\begin{array}{c}2.92 \pm 2.24 \\
(0.34-5.81)\end{array}$ & $\begin{array}{l}0.05 \pm 0.19 \\
(<\mathrm{DL}-0.75)\end{array}$ & $<\mathrm{DL}$ & & Lago (2006) \\
\hline
\end{tabular}

irreversible changes to ecological communities (Jackson et al., 2001), also affecting top-chain predators such as marine mammals (e.g. the modern extinction of the Yangtze river dolphin, Lipotes vexillifer, in China - Turvey et al., 2007). Despite this, few studies in the SWAO have investigated how dolphins respond to human-induced habitat modification in their natural environment. In the Itajaí River (SC), for example, the effects of anthropogenic activities (dredging, coastal engineering to expand the navigation channel and vessel traffic) on the occurrence and behavior of bottlenose dolphins was evaluated ${ }^{16}$. The engineering involved the use of explosives in order to remove submerged bedrock. The study detected changes to the dolphins' activity budgets, with a decrease in foraging and an increase in traveling ${ }^{16}$. A decline in dolphin sightings was also reported during the coastal work. Dredging activities also affected the relative presence and group size of dolphins in Itajaí River ${ }^{16}$.

The PLE, which comprises the second largest port in Brazil, has also faced intense human intervention (e.g. overfishing, expansion of jetties, dredging of estuarine channel) in the last decades (Kalikoski et al., 2002; Tagliani et al., 2007). The establishment of a major shipyard produced underwater noise and degradation to the estuarine margins. At the same time, work related to the jetty expansion occurred to allow the flow of ships with larger drafts by deepening the navigation channel through dredging and narrowing the channel connecting the Patos Lagoon with the Atlantic Ocean. The jetty expansion took place in a preferred dolphin use area (the mouth of the

\footnotetext{
${ }^{16}$ Britto, M.K. and Barreto, A.S. (2010) Effects of human activities on the behavior of bottlenose dolphins (Tursiops truncatus) in the Itajaí river mouth. Working Paper 39 presented during the First Workshop on the Research and Conservation of Tursiops truncatus: Integrating knowledge about the species in the Southwest Atlantic Ocean, 21-23 May 2010, Rio Grande, RS, Brazil.
}

estuary - see Mattos et al., 2007; Di Tullio et al., 2015) and involved placing rocks on the seabed using a variety of methods, as well as the placement of tetrapods (Figure 2). Opportunistic observations suggested short-term behavioral responses of the dolphins, with prolonged diving and temporary displacement during the activities (P. Fruet, pers. obs.). No long-term responses were observed, with dolphins which were regularly seen feeding at the end of the jetty continued to be seen feeding on the same general area after its expansion (i.e. as the piers extended, dolphins moved to their end to feed). The activities of the work do not seem to have had a prolonged negative effect on the dolphins' behavior and population dynamics (Fruet et al., 2015a, b). However, how dolphins will respond to the expected changes in ecosystem dynamics is still unknown. Narrowing of the single interface channel between the Patos Lagoon and the Atlantic Ocean is expected to increase outflow of river discharge (Fernandes et al., 2005), possibly acting as a barrier to the ingression of marine fish and crustacean larvae into the estuary (Vieira et al., 2008; Möller et al., 2009). As a consequence, a decrease in the abundance of marine fish assemblage in the estuary may occur, raising concerns about the local bottlenose dolphin population as they are known to feed exclusively on marine fish species ${ }^{17}$ (Pinedo, 1982; Mehsen et al., 2005).

The perception and understanding of structural changes and transitional processes in coastal marine ecosystems by both human disturbances and natural causes require the integration of research and monitoring of variables on a long-term basis

${ }^{17}$ Lopez, L.A., Di Tullio, J.C., Fruet, P.F. and Secchi, E.R. (2010). Alimentação do boto Tursiops truncatus no litoral sul do Rio Grande do Sul, Brasil. Working Paper 59 presented during the First Workshop on the Research and Conservation of Tursiops truncatus: Integrating knowledge about the species in the Southwest Atlantic Ocean, 21-23 May 2010, Rio Grande, RS, Brazil. 

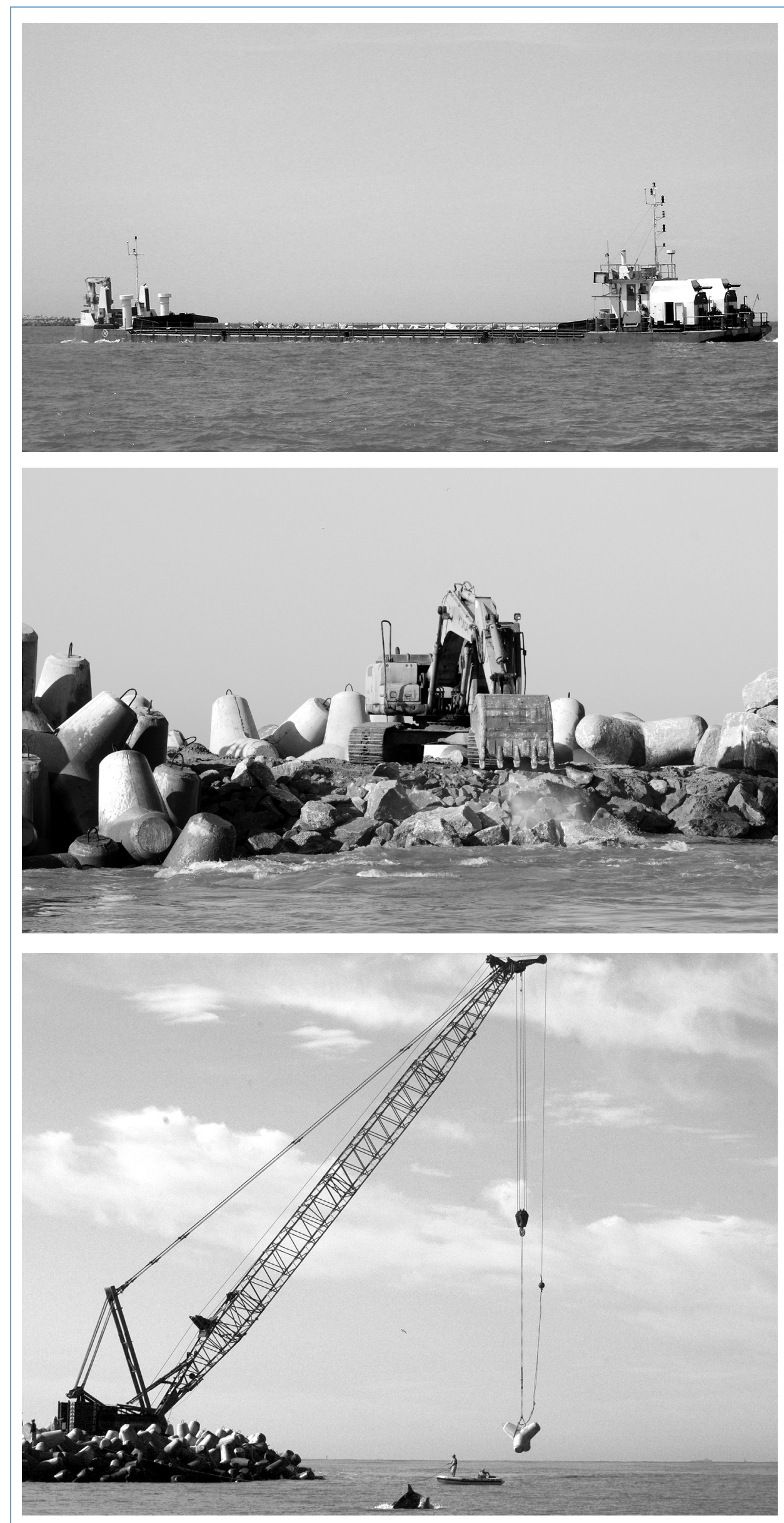

Figure 2. Activities conducted to expand the jetties in the Patos Lagoon Estuary. (A) Boat used to throw tons of rock to the seabed at the end of the jetties; (B) activity of throwing smaller rocks to the bottom of the sea by land when using trucks; (C) completion of work activities with the placement of tetrapods. 
(Seeliger and Costa, 2010). Only with the establishment of a continued monitoring will it be possible to elucidate the changes that may occur over the years and thus enable the provision of recommendations for the ecological sustainability of these and other environments that may receive similar development in coastal-estuarine areas.

\section{Interactions with tourism activities and boat traffic}

The potential impacts of boat traffic and tourism on cetaceans have been well documented and debated around the world in the past decade (e.g. Constantine, 2001; Lusseau, 2003; Williams et al., 2009; Parsons, 2012). For small cetaceans, vessel disturbance is of particular concern because it has been shown that dolphins can change their behavior as a response to boat approach or even avoid boats (Lusseau, 2003; Stensland and Berggren, 2007). This became a critical issue in areas of intensive dolphin watching or where there is a concentration of uncontrolled recreational boats because the presence of fast boats can easily disrupt natural dolphin activities and put them at risk of collision (e.g. Gubbins, 2002; Dwyer et al., 2014). Engine size and consequent underwater noise is also a source of disturbance, given cetaceans' reliance on acoustics for communication, orientation, and predator/ prey detection (e.g. Richardson et al., 1995; Tyack, 1998; Bejder et al., 2006; Martinez et al., 2012). Despite shortterm behavior effects of tourism on bottlenose dolphins have been well documented, little is known about how dolphins respond on the long-term. Some studies have shown a decline in relative abundance within the tourism site during a period of increased exposure to tour vessels (Bejder et al., 2006), and reduced reproductive success of populations by increased calf mortality due to collisions with such vessels (Lusseau et al., 2006).

Few dolphin-watching companies focus on bottlenose dolphins along the SWAO and the exposure to vessel disturbance occurs mainly in estuarine/coastal areas, where small populations co-exist with intense human activities. In the Cagarras Archipelago (RJ), a group of coastal islands in southeast Brazil, dolphins are exposed to impacts of tourism in an unregulated way (presence of fast boats, jet-skis and recreational diving disturb the dolphins' behavior), although no strikes have been recorded to date (Lodi et al., 2013). These activities are intensified in winter and spring, when a larger number of bottlenose dolphin groups, mostly composed of immature individuals, are observed in the area (Lodi, 2009). In Arraial do Cabo (RJ) interactions between dolphins and tourism boats are common along the year and are intensified during summer and weekends. In this area boat tourism is dedicated to cetacean observations, and bottlenose dolphins are one of the main targets due to their relative high abundance in the $\operatorname{area}^{2}$. However, no evaluation of the impacts of boat tourism on bottlenose dolphins has been conducted so far in Arraial do Cabo and Cagarras Archipelago.
The effects of boat traffic on a small group of bottlenose dolphins has been investigated in the Itajaí River $(\mathrm{SC})^{16}$, the largest and economically most important port of this State. A significant decrease in the sighting frequencies of dolphins in relation to boat traffic was reported. However, no significant changes in dolphin behavior was observed, possibly as the trade off for food supply is still positive in relation to vessel disturbance in favorable conditions of prey abundance ${ }^{16}$. No collisions between boats and bottlenose dolphins were registered, probably because of the sporadic presence of recreational boats in this area.

Around Florianópolis (SC) a well-established dolphin watching operation for Guiana dolphins has existed since the early 1980s (Pereira et al., 2007) and bottlenose dolphins are also targeted on occasion as they are found by boat operators mainly in summer (P. Flores, unpub. data). Usually, these dolphins do not show changes to their surface behavior (P. Flores, unpub. data), but a proper study assessing the potential effects of long-term disturbance of tourism upon bottlenose dolphins in Baía Norte (north portion of Florianópolis waters) is needed before a conclusion can be made.

In the Tramandaí River mouth (RS), small (8m) to midsize $(20 \mathrm{~m})$ vessels such as fishing boats and tugboats dominate boat traffic (Hoffmann, 1997; Moreno et al., 2009). A study of impacts of boats on dolphins in this area found no visible negative effects for the majority of vessel types when they were traveling at low speed (Hoffmann, 1997). Although dolphins generally approached motorboats and jet-skis at first contact, the animals tended to leave the river when tourist boats prolonged their presence in the area (Hoffmann, 1997). This is a particular cause of concern because this dolphin population is very small, and individuals perform a rare positive interaction with the artisanal fishermen, who depend, in part, on this interaction to catch fish (Simóes-Lopes et al., 1998). For local fishermen this uncontrolled tourism activity, which occurs mainly in January-February and June-July (main holiday periods in Brazil), is a source of concern, as is the intense boat traffic (Zappes et al., 2011a).

\section{Cooperative interactions between dolphins and artisanal fishermen}

In some areas bottlenose dolphins have developed feeding strategies to take advantage of human activities (Leatherwood and Reeves, 1983). There are different kinds of ecological interactions in which dolphins and fishermen may act as competitors, commensals or generating mutual advantages: cooperative or positive. Pryor et al. (1990) and Simóes-Lopes (1991) provided preliminary information on cooperative and spontaneous human-dolphin interactions in southern Brazil. Cooperative fishing with artisanal fishermen occurs mainly at the mouth of rivers or estuaries: Araranguá and Laguna (SC), Mampituba and Tramandaí rivers, and in the PLE (RS) (Simóes-Lopes, 1991; Zappes et al., 2011a; 2014). Cooperative fishing is initiated by the dolphins and is composed of ritualized 
movements that demand synchronization between both parties (Simóes-Lopes et al., 1998). Humans benefit from fish schools corralled by the dolphins, while dolphins catch disoriented and isolated fish. The influence of dolphins during cooperative fishing can be verified by increased capture efficiency and selectivity of larger prey when compared to an independent fishery (Simóes-Lopes et al., 1998).

The ritualized behavioral displays of the dolphins, the learning from mother to calf, and the participation of most of the individuals in these communities provide evidence of extra-human cultural transmission (Simóes-Lopes et al., 1998), which is reinforced by the high site fidelity of the individuals (Simóes-Lopes et al., 1998; Simóes-Lopes and Fabian, 1999; Daura-Jorge et al., 2012).

In most cases cooperative fishing takes place during fishing for mullet (Mugil spp.), which occurs mainly between autumn and winter in southern Brazil. In Laguna (SC) mullet comprised $92 \%$ of the total prey caught by fishermen, and in Tramandaí (RS) it is about 75\% (Simôes-Lopes et al., 1998). The gear employed by the artisanal fishermen during the cooperative fishing is called tarrafa de argola in Portuguese, a cast net of the falling type (for details see Peterson et al., 2008). In Laguna and Tramandaí mullet fishing has become a very important cultural event for the local community. In both locations dolphins were declared Patrimônio Natural Municipal (Natural Heritage of the City), emphasizing the positive feelings from the local population, and identifying the animals as friends of the fishermen, which improve family incomes and are also a tourism attraction (Peterson et al., 2008; Zappes et al., 2011a).

Despite seen as a positive interaction by the fishermen because they understand that the dolphins are assisting the fishing activities (e.g. Pryor et al., 1990; Simóes-Lopes et al., 1998; Zappes et al., 2011a), dolphins involved in cooperative fishing have increased risk of entanglement and injuries, as fishermen have reported dolphins removing and stealing fish from their cast nets and ripping the mesh if their calves get stuck in the cast net (Zappes et al., 2014). Damages to the nets and events whereby dolphins frighten the school away or deceive the fishermen by not correctly revealing the location of the school (Zappes et al., 2014) result in losses for the artisanal fishermen.

\section{Conclusions}

The data compiled in this review demonstrate that coastal bottlenose dolphins are under anthropogenic pressure in the SWAO. There are several potential sources of impact and some populations may be especially vulnerable, such as the resident populations inhabiting the Patos Lagoon Estuary and the coastal waters of Argentina. However, in general, the studies are scarce or preliminary - a great effort is still required to understand the real impact of human activities on bottlenose dolphins in the SWAO. The main conclusions of this report are:
1. Direct take of bottlenose dolphins in the wild does not appear to be an issue of conservation concern;

2. Incidental captures occur throughout the species distribution and seem to be occasional in Uruguayan and Argentinean waters, where there is evidence of a historic decline in dolphin sightings. In Brazil, bycatch is apparently low in the northeast and southeast coasts, but is frequent in certain areas of southern Brazil, especially in areas close to the PLE, where it seems to occur in high rates in relation to the dolphin population size;

3. Specific data from fisheries (e.g. target species, net mesh size, depth and location of fisheries) harming bottlenose dolphins in SWAO are still scarce, but there is evidence suggesting coastal artisanal gillnet fisheries, which operate very close to shore and target demersal fishes, are the main type of fisheries impacting upon coastal bottlenose dolphins;

4. The bottlenose dolphins are exposed to bioaccumulation of micropollutants along the SWAO. Populations near or under influence of large urban centers may be especially vulnerable to accumulate higher concentrations. However, the studies are still extremely scarce and sample numbers are low;

5. Coastal works (e.g. dredging, coastal engineering to extend jetties), vessel traffic and dolphin-watching tourism disrupt natural behaviour and habitat use of bottlenose dolphins at least in the short-term. Potential long-term impacts of these activities on bottlenose dolphins in the SWAO remain undetected;

6. Dolphin cooperative fishing with artisanal fishermen occurs mainly in south Brazil, especially at the mouth of Laguna, and Mampituba and Tramandaí rivers. Despite cooperative fishing increasing the capture efficiency of fishermen, the effects of this activity on bottlenose dolphins are still unknown.

\section{Recommendations}

1. The implementation of an integrated systematic monitoring program of the main artisanal fishing fleets operating in coastal waters of southern Brazil, Uruguay and Argentina is highly recommended since the presence of coastal bottlenose dolphins is common in these waters. This program should focus on obtaining standard information such as: current fleet size, preferred fishing areas, main target species, fishery characteristics (net type, mesh and size), fishery effort, numbers of incidental captures of cetaceans and other marine mammals. This information could be obtained in partnership with stakeholders through local knowledge in addition to studies of the fisheries carried out by researchers;

2. To conduct studies to investigate levels of micropollutants in bottlenose dolphins from the SWAO, taking into account the effects of ontogeny and life history parameters. It is suggested that the use of biopsy sampling from bottlenose dolphins to obtain tissue samples may be more effective. Also, it is recommended to perform studies regarding pollutantpathology relationships through biomarker analyses;

3. To conduct studies aimed at estimating the rate of 
injuries on bottlenose dolphins caused by fishery interaction and boat strikes. This information could be accessed through analysis of the current available photo-identification databases from different regions;

4. To elaborate regulations for tourism activities on bottlenose dolphins along coastal areas in the SWAO. This could be based on the best-documented studies, such as Shark Bay, Australia (Bejder et al., 2006) and Fiordland, New Zealand (Lusseau et al., 2006). This precautionary approach should be sustained until the effects of tourism and recreational boat traffic have been properly measured.

\section{Acknowledgments}

The authors thank E. Secchi, R. Bastida, D. Palacios and two anonymous reviewers for their constructive comments on the early draft of this manuscript.

\section{References}

Aguilar, A., Borrell, A. and Pastor, T. (1999) Biological factors affecting variability of persistent pollutant levels in cetaceans. Journal of Cetacean Research and Management 1 (Special Issue 1): 83-116.

Barros, N.B. (1991) Recent cetacean records for Southeastern Brazil. Marine Mammal Science 7(3): 296-306.

Bejder, L., Samuels, A., Whitehead, H., Gales, N., Mann, J., Connor, R., Heithaus, M., Watson-Capps, J., Flaherty, C. and Krützen, M. (2006) Decline in relative abundance of bottlenose dolphins (Tursiops sp) exposed to long-term disturbance. Conservation Biology 20(6): 1791-1798.

Bisi, T.L., Lepoint, G., Azevedo, A.F., Dorneles, P.R., Flach, L., Das, K., Malm, O. and Lailson-Brito, J. (2012) Trophic relationships and mercury biomagnification in Brazilian tropical coastal food webs. Ecological Indicators 18: 291-302.

Bordino, P., Graus, S., Albareda, D., Fazio, A., Palmerio, A., Mendez, M. and Botta, S. (2002) Reducing incidental mortality of franciscana dolphin Pontoporia blainvillei with acoustic warning devices attached to fishing nets. Marine Mammal Science 18(4): 833-842.

Burkhart, S.M. and Slooten, E. (2003) Population viability analysis for Hector's dolphin (Cephalorhynchus hectori): A stochastic population model for local populations. New Zealand Journal of Marine and Freshwater Research 37(3): 553-566.

Bustamante, P., Caurant, F., Fowler, S.W. and Miramand, P. (1998) Cephalopods as a vector for the transfer of cadmium to top marine predators in the north-east Atlantic Ocean. Science of the Total Environment 220(1): 71-80.

Capelli, R., Das, K., Pellegrini, R.D., Drava, G., Lepoint, G., Miglio, C., Minganti, V. and Poggi, R. (2008) Distribution of trace elements in organs of six species of cetaceans from the Ligurian Sea (Mediterranean), and the relationship with stable carbon and nitrogen ratios. Science of the Total Environment 390(2-3): 569-578.
Constantine, R. (2001) Increased avoidance of swimmers by wild bottlenose dolphins (Tursiops truncatus) due to long-term exposure to swim-with-dolphin tourism. Marine Mammal Science 17(4): 689-702.

Corcuera, J., Monzón, F., Crespo, E.A., Aguilar, A. and Raga, J.A. (1994) Interactions between marine mammals and coastal fisheries of Necochea and Claromecó (Buenos Aires Province, Argentina). Pages 283-290 in Perrin, W.F., Donovan, G.P. and Barlow, J. (Eds) Report of the International Whaling Commission (Special Issue 15). Cambridge, England.

Corsolini, S., Focardia, S., Kannan, K., Tanabe, S., Borrel, A. and Tatsukawa, R. (1995) Congener profile and toxicity assessment of polychlorinated biphenyls in dolphins, sharks and tuna collected from Italian coastal waters. Marine Environmental Research 40 (1): 33-53.

Covaci, A., Van de Vijver, K., De Coen, W.M., Das, K., Bouquegneau, J.M., Blust, R. and Schepens, P. (2002) Determination of organohalogenated contaminants in liver of harbour porpoises (Phocoena phocoena) stranded on the Belgian North Sea coast. Marine Pollution Bulletin 44(10): 1157-1169.

Crespo, E.A., Corcuera, J.F. and Lopez, C.A. (1994) Interactions between marine mammals and fisheries in some coastal fishing areas of Argentina. Pages 269-281 in Perrin, W.F., Donovan, G.P. and Barlow, J. (Eds) Report of the International Whaling Commission (Special Issue 15). Cambridge, England.

Crespo, E.A., Pedraza, S.N., Dans, S.L., Koen Alonso, M., Reyes, L.M., García, N.A. and Coscarella, M. (1997) Direct and indirect effects of the highseas fisheries on the marine mammal populations in the Northern and Central Patagonian Coast. Journal Northwestern Atlantic Fisheries Science 22: 189-207.

Crespo, E.A., Koen Alonso, M., Dans, S.L., García, N.A., Pedraza, S.N., Coscarella, M. and González, R. (2000) Incidental catches of dolphins in mid-water trawls for Argentine anchovy (Engraulis anchoita) off the Argentine shelf. Journal of Cetacean Research and Management 2(1): 11-16.

Crespo, E.A., García, N.A., Dans, S.L. and Pedraza, S.N. (2008) Mamíferos Marinos. Tursiops truncatus. Pages 1-6 in Boltovskoy, D. (Ed.) Atlas de Sensibilidad Ambiental del Mar y la costa Patagónica. Secretaría de Ambiente y Desarrollo Sustentable de la Nación (Proyecto ARG 02/018 Conservación de la Diversidad Biológica y Prevención de la Contaminación Marina en Patagonia). Buenos Aires, Argentina.

http://atlas.ambiente.gov.ar

Dans, S.L., Crespo, E.A., Garcia, N.A., Reyes, L.M., Pedraza, S.N. and Koen Alonso, M. (1997) Incidental mortality of Patagonian dusky dolphins in mid-water trawling: retrospective effects from the early 80s. Report of the International Whaling Commission 47: 699-704. Cambridge, England. 
Das, K., Debacker, V., Pillet, S. and Bouquegneau, J.M. (2003) Heavy metals in marine mammals. Pages 135-167 in Vos, J.G., Bossart, G., Fournier, M. and O’Shea, T. (Eds) Toxicology of Marine Mammals. Taylor and Francis Publishers, Washington D.C., USA.

Daura-Jorge, F.G., Cantor, M., Ingram, S.N., Lusseau, D. and Simóes-Lopes, P.C. (2012) The structure of a bottlenose dolphin society is coupled to a unique foraging cooperation with artisanal fishermen. Biology Letters 8: 702-70.

Delfino, E., Fabiano, G. and Santana, O. (2003) La pesca artesanal en La Paloma (Rocha, Uruguay): período 19992000. Pages 567-576 in Menafra, R., Rodriguez-Gallego, L., Scarabino, F. and Conde, D. (Eds) Bases para la conservación y el manejo de la costa Uruguaya.Vida Silvestre, Montevideo, Uruguay.

Di Beneditto, A.P. (2003) Interactions between gillnet fisheries and small cetaceans in northern Rio de Janeiro, Brazil: 2001-2002. Latin American Journal of Aquatic Mammals 2(2): 79-86.

Di Beneditto, A.P., Ramos, R. and Lima, N.R.W. (1998) Fishing activity in northern Rio de Janeiro State (Brazil) and its relation with small cetaceans. Brazilian Archives of Biology and Technology 41(3): 296-302.

Di Tullio, J.C., Fruet, P.F. and Secchi, E.R. (2015) Identifying critical areas to reduce bycatch of coastal common bottlenose dolphins Tursiops truncatus in artisanal fisheries of the subtropical western South Atlantic. Endangered Species Research 29: 35-50.

Domingo, A., Bugoni, L., Prosdocimi, P., Miller, M., Laporta, P., Monteiro, D.S., Estrades, A. and Albareda, D. (2006) The impact generated by fisheries on sea turtles in the Southwestern Atlantic. WWF Programa Marino para Latinoamérica y el Caribe. San José, Costa Rica.

Dorneles, P.R., Lailson-Brito J., Santos, R.A., Costa, P.A.S., Malm, O., Azevedo, A.F. and Torres, J.P.M. (2007) Cephalopods and cetaceans as indicators of offshore bioavailability of cadmium off Central South Brazil Bight. Environmental Pollution 148(1): 352-359.

Dorneles, P.R., Lailson-Brito, J., Fernandez, M.A.S., Vidal, L.G., Barbosa, L.A., Azevedo, A.F., Fragoso, A.B.L., Torres, J.P.M. and Malm, O. (2008a) Evaluation of cetacean exposure to organotin compounds in Brazilian waters through hepatic total tin concentrations. Environmental Pollution 156(3): 1268-1276.

Dorneles, P.R., Lailson-Brito, J., Meyer, J., Lepoint, G., Azevedo, A.F., Torres, J.P.M., Malm, O., Blust, R. and Das, K. (2008b) Link between marine mammal exposure to perfluooctane sulfonate (PFOS) and stable-carbon isotope ratios in neritic and oceanic waters off Brazil. Organohalogen Compounds 70: 1669-1672.
Dorneles, P.R., Lailson-Brito, J., Dirtu, A.C., Weijs, L., Azevedo, A.F., Torres, J.P.M., Malm, O., Neels, H., Blust, R., Das, K. and Covaci, A. (2010) Anthropogenic and naturally produced organobrominated compounds in marine mammals from Brazil. Environment International 36(1): 60-67.

Dwyer, S.L., Kozmian-Ledward, L. and Stockin, K.A. (2014) Short-term survival of severe propeller strike injuries and observations on wound progression in a bottlenose dolphin. New Zealand Journal of Marine and Freshwater Research 48(2): 294-302.

Fernandes, E.H., Cecílio, R.O. and Schiller, R.V. (2005) Estudo da influência dos molhes da barra de Rio Grande sobre a circulação do estuário da Lagoa dos Patos. Vetor 15(2): 40-57.

Franco-Trecu, V., Costa, P., Abud, C., Dimitriadis, C., Laporta, P., Passadore, C. and Szephegyi, M. (2009) By-catch of franciscana Pontoporia blainvillei in Uruguayan artisanal gillnet fisheries: an evaluation after a twelve-year gap in data collection. Latin American Journal of Aquatic Mammals 7(12): 11-22.

Fruet, P.F., Kinas, P.G., Silva, K.G., Di Tullio, J.C., Monteiro, D., Dalla Rosa, L., Estima, S. and Secchi, E.R. (2012) Temporal trends in mortality and effects of by-catch on common bottlenose dolphins, Tursiops truncatus, in southern Brazil. Journal of the Marine Biological Association of the United Kingdom 92(8): 1865-1876.

Fruet P.F., Secchi, E.R., Daura-Jorge, F., Vermeulen, E., Flores, P.A.C., Simóes-Lopes, P.C., Genoves, R.C., Laporta, P., Di Tullio, J.C., Freitas, T.R.O., Dalla Rosa, L., Valiati, V.H., Beheregaray, L.B. and Möller, L.M. (2014) Remarkably low genetic diversity and strong population structure in common bottlenose dolphins (Tursiops truncatus) from coastal waters of the Southwestern Atlantic Ocean. Conservation Genetics 15(4): 879-889.

Fruet, P.F., Genoves, R.C., Möller, L.M., Botta, S. and Secchi, E.R. (2015a) Using mark-recapture and stranding data to estimate reproductive traits in female bottlenose dolphins (Tursiops truncatus) of the Southwestern Atlantic Ocean. Marine Biology 162(3): 661-673.

Fruet, P.F., Daura-Jorge, F.G., Möller, L.M., Genoves, R.C. and Secchi, E.R. (2015b) Abundance and demography of bottlenose dolphins inhabiting a subtropical estuary in the Southwestern Atlantic Ocean. Journal of Mammalogy 96(2): 332-343.

Fruet, P.F., Laporta, P., and Flores, P.A. (2016) Report of the working group on population parameters and demography of Tursiops truncatus in the Southwest Atlantic Ocean. Latin American Journal of Aquatic Mammals 11(1-2): 71-78. http://dx.doi.org/10.5597/lajam00217

Gilpin, M.E. and Soulé, M.E. (1986) Minimum viable populations: process of species extinction. Pages 19-34 in Soulé, M.E. (Ed.) Conservation biology: the science of scarcity and diversity. Sinauer Associates, Sunderland, USA. 
Goodall, R.N.P., Galeazzi, A.R. and Lichter, A.A. (1988) Exploitation of small cetaceans off Argentina 1979-1986. Report of the International Whaling Commission 38: 407-10.

Goodall, R.N.P., Schiavini, A.C.M. and Fermani, C. (1994) Net fisheries and net mortality of small cetaceans off Tierra del Fuego, Argentina. Pages 295-306 in Perrin, W.F., Donovan, G.P. and Barlow, J. (Eds) Report of the International Whaling Commission (Special Issue 15). Cambridge, England.

Gray, J.S. (2002) Biomagnification in marine systems: the perspective of an ecologist. Marine Pollution Bulletin 45(112): 46-52.

Gubbins, C.M. (2002) Association patterns of resident bottlenose dolphins (Tursiops truncatus) in a South Carolina estuary. Aquatic Mammals 28(1): 24-31.

Haimovici, M., Castello, J.P. and Vooren, C.M. (1997) Fisheries. Pages 183-196 in Seeliger, U., Odebrecht, C. and Castello, J.P. (Eds) Subtropical Convergence Environments. The Coast and Sea in the Southwestern Atlantic. Springer, Berlin.

Hansen, L.J., Schwacke, L.H., Mitchum, G.B., Hohn, A.A., Wells, R.S., Zolman, E.S. and Fair, P. (2004) Geographic variation in polychorinated biphenyl and organochlorine pesticide concentrations in the blubber of bottlenose dolphins from the U.S. Atlantic coast. Science of the Total Environment 319(1-3): 147-172.

Hoffmann, L.S. (1997) Padrōes de associação, ocupação do habitat e aspectos ecológicos de Tursiops truncatus (Montagu, 1821) (Cetacea, Delphinidae) no sul do Brasil. M.Sc. Thesis. Universidade Federal do Rio Grande do Sul. Porto Alegre, Brasil. 85 pp.

Jackson, J.B.C., Kirby, M.X., Berger, W.H., Bjorndal, K., Botsford, L.W., Bourque, B.J., Bradbury, R.H., Cooke, R., Erlandson, J., Estes, J.A., Hughes, T.P., Kidwell, S., Lange, C.B., Lenihan, H.S., Pandolfi, J.M., Peterson, C.H., Steneck, R.S., Tegner, M.J. and Warner, R.R. (2001) Historical overfishing and the recent collapse of coastal ecosystems. Science 293(5530): 629-638.

Kalikoski, D.C. (2002) The Forum of Patos Lagoon: An analysis of institutional arrangements for conservation of coastal resources in southern Brazil. Ph.D. Thesis. University of British Columbia, Canada. 257 pp.

Kalikoski, D.C., Vasconcellos, M. and Lavkulich, L. (2002) Fitting institutions to ecosystems: The case of artisanal fisheries management in the estuary of Patos Lagoon. Marine Policy 26(3): 179-196.

Kjerfve, B., Ribeiro, C.H.A., Dias, G.T.M., Filippo, A.M. and Da Silva Quaresma, V. (1997) Oceanographic characteristics of an impacted coastal bay: Baía de Guanabara, Rio de Janeiro, Brazil. Continental Shelf Research 17(13): 1609-1643.
Klippel, S., Peres, M.B., Vooren, C.M. and Lamónaca, A.F. (2005) A pesca artesanal na costa da Plataforma Sul. Pages 179_ 197 in Vooren, C.M. and Klippel, S. (Eds) Açóes para conservação de tubaróes e raias no sul do Brasil. Igaré, Porto Alegre, Brasil.

Lago, C.F. (2006) Organoclorados na população do cetáceo Tursiops truncatus (Montagu, 1821) do extremo sul do Brasil. Monograph. Universidade Federal do Rio Grande. Rio Grande, Brazil. 57 pp.

Lahille, F. (1908) Nota sobre un delfín (Tursiops gephyreus Lah.). Anales del Museo Nacional de Buenos Aires XVI(3): 347-365.

Lailson-Brito, J., Dorneles, P.R., Azevedo-Silva, C.E., Azevedo, A.F., Vidal, L.G., Azeredo, A., Fragoso, A.B.L., Cunha, H.A., Torres, J.P.M. and Malm, O. (2010) High organochlorine accumulation in blubber of Guiana dolphin, Sotalia guianensis, from Brazilian coast and its use to establish geographical differences among populations. Environmental Pollution 158(5): 1800-1808.

Lailson-Brito, J., Dorneles, P.R., Azevedo-Silva, C.A., Bisi, T.L., Vidal, L.G., Legat, L., Azevedo, A.F., Torres, J.P.M. and Malm, O. (2012) Organochlorine compound accumulation in delphinids from Rio de Janeiro State, southeastern Brazilian coast. Science of the Total Environment 433(2012): 123-131.

Laporta, P. (2009) Abundância, distribuição e uso de habitat do boto (Tursiops truncatus) em La Coronilla e Cabo Polonio, Rocha, Uruguay. M.Sc. Thesis. Universidade Federal de Rio Grande. Rio Grande, Brazil. 179 pp.

Laporta, M., Miller, P., Ríos, M., Lezama, C., Bauzá, A., Aisenberg, A., Pastorino, V. and Fallabrino, A. (2006) Conservación y manejo de tortugas marinas en la costa uruguaya. Pages 259-269 in Menafra, R., RodríguezGallego, L., Scarabino, F. and Conde, D. (Eds) Bases para la conservación y manejo de la costa Uruguaya. Vida Silvestre, Montevideo, Uruguay.

Leatherwood, S. and Reeves, R.R. (1983) The Sierra Club Handbook of whales and dolphins. The Sierra Club Books. San Francisco, USA.

Lodi, L. (2009) Fidelidade de área, características de grupo e organizaçâo social de Tursiops truncatus (Cetacea, Delphinidade) no Arquipélago das Cagarras, Rio de Janeiro, RJ, Brasil. Ph.D. Thesis. Universidade Federal Fluminense. Rio de Janeiro, Brazil. 267 pp.

Lodi, L., Mayerhofer, L.C. and Monteiro-Neto, C. (2009) Evaluation of the video-identification technique applied to bottlenose dolphins (Tursiops truncatus) in Cagarras Archipelago, Rio de Janeiro, Brazil. Journal of the Marine and Biological Association of United Kingdom 89(Special Issue 5): 1077-1081. 
Lodi, L., Zappes, C.A. and Santos, A.S.G. (2013) Aspectos etnoecológicos e implicaçóes para a conservação de Tursiops truncatus (Cetartiodactyla: Delphinidae) no Arquipélago das Cagarras, Rio de Janeiro, Brasil. Sitientibus série Ciências Biológicas 13. http://dx.doi.org/10.13102/scb200

Lusseau, D. (2003) Effects of tour boats on the behavior of bottlenose dolphins: Using Markov chains to model anthropogenic impacts. Conservation Biology 17(6): 1785-1793.

Lusseau, D., Slooten, L. and Currey, R.J.C. (2006) Unsustainable dolphin-watching tourism in Fiordland, New Zealand. Tourism in Marine Environments 3(2): 173-178.

Marcovecchio, J.E., Moreno, V.J., Bastida, R.O., Gerpe, M.S. and Rodríguez, D.H. (1990) Tissue distribution of heavy metals in small cetaceans from the Southwestern Atlantic Ocean. Marine Pollution Bulletin 21(6): 299-304.

Marcovecchio, J.E., Gerpe, M.S., Bastida, R.O. Rodríguez, D.H. and Morón, S.G. (1994) Environmental contamination and marine mammals in coastal waters from Argentina: an overview. Science of Total Environment 154(2-3): 141-51.

Marigo, J. and Giffoni, B.B. (2010) Sightings and bycatch of small pelagic cetaceans, new information registered by volunteer fishermen of São Paulo, Brazil. Brazilian Journal of Oceanography 58(1): 71-75.

Martinez, E., Orams, M.B., Pawley, M.D.M. and Stockin, K.A. (2012) The use of auditory stimulants during swim encounters with Hector's dolphins (Cephalorhynchus hectori hectori) in Akaroa Harbour, New Zealand. Marine Mammal Science 28(3): E295-E315.

http://dx.doi.org/10.1111/j.1748-7692.2011.00528.x

Mattos, P.H., Dalla Rosa, L. and Fruet, P.F. (2007) Activity budgets and distribution of bottlenose dolphins (Tursiops truncatus) in the Patos Lagoon estuary, southern Brazil. Latin American Journal of Aquatic Mammals 6(2): 161-169.

McConnaughy, T. and McRoy, C.P. (1979) Food-web structure and the fractionation of carbon isotopes in the Bering Sea. Marine Biology 53(4): 257-262.

Mehsen M., Secchi E.R., Fruet, P.F. and Di Tullio, J. (2005) Feeding habits of bottlenose dolphins, Tursiops truncatus, in southern Brazil. Paper SC/58/SM8 presented to the Scientific Committee, International Whaling Commission, Ulsan, South Korea. [Available online from <http://www. botosdalagoa.com.br/arquivos/docB.pdf > ]

Meirelles A.C.O., Monteiro-Neto, C., Martins, A.M.A., Costa, A.F., Barros, H.M.D.R. and Alves, M.D.O. (2009) Cetacean strandings in Ceará coast, north-eastern Brazil (1992-2005). Journal of the Marine Biological Association of the United Kingdom 89(5): 1083-1090.
Meirelles, A.C.O., Campos, T.M., Marcondes, M.C.C., Groch, K.R., Souto, L.R.A., Reis, M.S.S., Normande, I., Luna, F.O., Nascimento, L.F., Silva, F.J.L., Vergara-Parente, J.E., Borges, J.C.G., Jesus, A.H., Attademo, F.L.N. and Silva Jr, J.M. (2016) Reports of strandings and sightings of bottlenose dolphins (Tursiops truncatus) in northeastern Brazil and Brazilian oceanic islands. Latin American Journal of Aquatic Mammals 11(1-2): 178-190.

http://dx.doi.org/10.5597/lajam00227

Michener, R.H. and Kaufman, L. (2007) Stable isotope ratios as tracers in marine food webs: an update. Pages 238-282 in Michener, R.H. and Lajtha, K. (Eds) Stable Isotopes in Ecology and Environmental Science. Wiley-Blackwell, Oxford.

Möller, O.O., Castello, J.P. and Vaz, A.C. (2009) The effect of river discharge and winds on the interannual variability of the pink shrimp Farfantepenaeus paulensis production in Patos Lagoon. Estuaries and Coasts 32(4): 787-796.

Moreno, V.J., Pérez, A., Bastida, R.O., De Moreno, J.E.A. and Malaspina, A.M. (1984) Distribución de mercúrio total em los tejidos de un delfin nariz de botella (Tursiops gephyreus Lahille, 1902) de La Provincia de Buenos Aires, AR. Revista de Investigación y Desarrollo Pesquero 4: 93-103.

Moreno, I.B., Tavares, M., Danilewicz, D., Ott, P.H. and Machado, R. (2009) Descrição da pesca costeira de media escala no litoral norte do Rio Grande do Sul: comunidades pesqueiras de Imbé/Tramandaí e Passo de Torres/Torres. Boletim do Instituto de Pesca de Sáo Paulo 35(1): 129-140.

Morris, R.J., Law, R.J., Allchin, C.R., Kelly, C.A. and Fillmann, C.F. (1989) Metals and organochlorines in dolphins and porpoises of Cardigan Bay, west Wales. Marine Pollution Bulletin 20(10): 512-523.

Moura, J.F., Tavares, D.C., Secco, H.K.C. and Siciliano, S. (2016) Bottlenose dolphins (Tursiops truncatus, Montagu 1821) in central-northern coast of Rio de Janeiro State, Brazil: stranding patterns and insights into feeding habits. Latin American Journal of Aquatic Mammals 11(1-2): 191198. http://dx.doi.org/10.5597/lajam00228

Netto, F.R. and Barbosa, L.A. (2003) Cetaceans and fishery interactions along the Espírito Santo State, southeastern Brazil during 1994-2001. Latin American Journal of Aquatic Mammals 2(1): 57-60.

Netto, F.R. and Di Beneditto, A.P. (2008) Interactions between fisheries and cetaceans in Espírito Santo State coast, southeastern Brazil. Revista Brasileira de Zoociências 10(1): 55-63.

Parsons, E.C.M. (2012) The negative impacts of whalewatching. Journal of Marine Biology.

http://dx.doi.org/10.1155/2012/807294 
Passadore, C., Domingo, A. and Secchi, E.R. (2015) Analysis of marine mammal bycatch in the Uruguayan pelagic longline fishery operating in the Southwestern Atlantic Ocean. ICES Journal of Marine Science 72(5): 1637-1652.

http://dx.doi.org/10.1093/icesjms/fsu250

Pereira, M.G., Bazzalo, M. and Flores, P.A.C. (2007) Reaçôes comportamentais na superfície de Sotalia guianensis (Cetacea, Delphinidae) durante encontros com embarcaçóes na Baía Norte de Santa Catarina. Zoociências 9(2): 123-135.

Pérez Macri, G. and Crespo, E.A. (1989) Survey of the franciscana dolphin (Pontoporia blainvillei) along the Argentine coast with a preliminary evaluation of incidental mortality in coastal fisheries. Pages 57-63 in Perrin, W.F., Brownell Jr, R.L., Jiankang, L. and Kaiya, Z. (Eds) Biology and Conservation of the River Dolphins. Occasional papers of the IUCN Species Survival Commission (SSC) No. 3.

Peterson, D., Hanazaki, N. and Simões-Lopes, P.C. (2008) Natural resource appropriation in cooperative artisanal fishing between fishermen and dolphins (Tursiops truncatus) in Laguna, Brazil. Ocean \& Coastal Management 51(6): 469-475.

Pilleri, G. and Gihr, M. (1972) Record and taxonomy of Tursiops gephyreus (Lahille 1908) from playa Coronilla Uruguay. Investigations on Cetacea 4: 173-181.

Pin, O.D., Arena, G., Chiesa, E. and Puig, P. (2003) Abundancia, capturas y medidas de manejo del recurso corvina (Micropogonias furnieri) en el Río de la Plata y Zona Común de Pesca Argentino-Uruguaya (1975-2003). Pages 225-232 in Menafra, R., Rodriguez-Gallego, L., Scarabino, F. and Conde, D. (Eds) Bases para la conservación y el manejo de la costa Uruguaya. Vida Silvestre, Montevideo, Uruguay.

Pinedo, M.C. (1982) Análise dos conteúdos estomacais de Pontoporia blanvillei (Gervais e D'Orbigny, 1844) e Tursiops gephyreus (Lahille, 1908) (Cetacea, Platanistidae e Delphinidae) na zona estuarial e costeira de Rio Grande, RS, Brasil. M.Sc. Thesis. Universidade Federal do Rio Grande. Rio Grande, Brazil. 95 pp.

Pinedo, M.C. and Polacheck, T. (1999) Trends in franciscana (Pontoporia blainvillei) stranding rates in Rio Grande do Sul, southern Brazil (1979-1998). Journal of Cetacean Research and Management 1(2): 179-189.

Praderi, R. (1985) Incidental mortality of dolphins (Pontoporia blainvillei) in Uruguay. National Geographic Society Research Reports 21: 395-403.

Prado, J.H.F. (2016) Padróes temporais no encalhe de mamiferos marinhos e identificação de áreas de risco de capturas acidentais de toninha, Pontoria blainvillei, no sul do Brasil. Ph.D. Thesis. Universidade Federal do Rio Grande. Rio Grande, Brazil. 106 pp.
Prado, J.H.F., Secchi, E.R. and Kinas, P.G. (2013) Markrecapture of the endangered franciscana dolphin (Pontoporia blainvillei) killed in gillnet fisheries to estimate past bycatch from time series of stranded carcasses in southern Brazil. Ecological Indicators 32(2013): 35-41.

Pryor, K., Lindbergh, J., Lindbergh, S. and Milano, R. (1990) A dolphin-human cooperative in Brazil. Marine Mammal Science 6(1): 77-82.

Read, A.J., Drinker, P. and Northridge, S. (2006) By-catch of marine mammals in the U.S. and global fisheries. Conservation Biology 20(1): 163-169.

Reeves, R.R., Smith, B.D., Crespo, E.A. and Notarbartolo di Sciara, N. (2003) Dolphins, whales and porpoises: 2002-2010 conservation action plan for the world's cetaceans. International Union for the Conservation of Nature and Natural Resources. Gland, Switzerland.

Reeves, R.R., McClellan, K., and Werner, T.B. (2013) Marine mammal bycatch in gillnet and other entangling net fisheries, 1990 to 2011. Endangered Species Research 20(1): 71-97.

Reis, E.G. (1992) An assessment of the exploitation of the white croacker Micropogonias furnieri (Pisces, Sciaenidae) by the artisanal and industrial fisheries in coastal waters of southern Brazil. Ph.D. Thesis. University of East Anglia. Norwich, England. 212 pp.

Richardson, W.J., Greene, C.R., Malme, C.I., Thomsen, D.H., Moore, S.E. and Würsig, B. (1995) Marine mammals and noise. Academic Press, San Diego, California.

Santos, M.C.O., Siciliano, S., Vicente, A.F.C., Alvarenga, F.S., Zampirolli, E., Souza, S.P. and Maranho, A. (2010) Cetacean records along São Paulo State coast, Southeast Brazil. Brazilian Journal of Oceanography 58(2): 123-142. http://dx.doi.org/10.1590/S1679-87592010000200004

Secchi, E.R. (2010) Review on the threats and conservation status of franciscana, Pontoporia blainvillei (Cetacea, Pontoporiidae). Pages 323-339 in Ruiz-Garcia, M. and Shostell, J.M. (Eds) Biology, Evolution and Conservation of River Dolphins Within South America and Asia. Nova Science Publishers Inc., New York, USA.

Secchi, E.R. (2014) Family Pontoporiidae (Franciscana). Pages 386-393 in Wilson, D.E. and Mittermeier, R.A. (Eds) Handbook of the Mammals of the World. Vol. 4. Sea Mammals. Lynx Edicions, Barcelona.

Seeliger, U. and Costa, C.S.B. (2010) Liçôes ecológicas e futuras tendências. Pages 147-149 in Seeliger, U. and Odebrecht, C. (Eds) O estuário da Lagoa dos Patos: Um século de transformação. Fundação Universidade do Rio Grande, Rio Grande, Brazil. 
Siciliano, S. (1994) Review of small cetaceans and fishery interactions in coastal waters of Brazil. Pages 241-250 in Perrin, W.F., Donovan, G.P. and Barlow, J. (Eds) Report of the International Whaling Commission (Special Issue 15). Cambridge, England.

Sidou, S.A. (2008) Capturas acidentais de pequenos cetáceos pela frota pesqueira do porto de Cananéia, SP. Monograph. Universidade Estadual Paulista. Rio Claro, Brasil. 127 pp.

Simóes-Lopes, P.C. (1991) Interaction of costal populations of Tursiops truncatus (Cetacea, Delphinidae) with the mullet artisanal fisheries in southern Brazil. Biotemas 4(2): 83-94.

Simóes-Lopes, P.C. and Ximenez, A. (1993) Annotated list of the cetaceans of Santa Catarina coastal waters, southern Brazil. Biotemas 6(1): 67-92.

Simóes-Lopes, P.C. and Fabian, M.E. (1999) Residence patterns and site fidelity in bottlenose dolphins, Tursiops truncatus (Montagu) (Cetacea, Delphinidae) off Southern Brazil. Revista Brasileira de Zoologia 16(4): 1017-1024.

Simôes-Lopes, P.C., Fabian, M.E. and Menegheti, J.O. (1998) Dolphin interactions with the mullet artisanal fishing on Southern Brazil: a qualitative and quantitative approach. Revista Brasileira de Zoologia 15(3): 709-726.

Stensland, E. and Berggren, P. (2007) Behavioural changes in female Indo-Pacific bottlenose dolphins in response to boatbased tourism. Marine Ecology Progress Series 332: 225-234.

Tagliani, P.R.A., Asmus, M.L., Tagliani, C.R.A, Polette, M., Costa, C.S.B. and Salas, E. (2007) Integrated coastal zone management in the Patos Lagoon Estuary (South Brazil): state of art. Ocean \& Coastal Management 46(9-10): 807-822.

Tanabe, S. (1999) Butyltin contamination in marine mammals - a review. Marine Pollution Bulletin 39(1): 62-72.

Turvey, S.T., Pitman, R.L., Taylor, B.L., Barlow, J., Akamatsu, T., Barrett, L.A., Zhao, X., Reeves, R.R., Stewart, B.S., Wang, K., Wei, Z., Zhang, X., Pusser, L.T., Richlen, M., Brandon, J.R. and Wang, D. (2007) First human-caused extinction of a cetacean species? Biology Letters 3(5): 537-540.

Tyack, P.L. (1998) Acoustic communication under the sea. Pages 163-220 in Hopp, S.L. and Evans, C.S. (Eds) Acoustic communication in animals. Springer-Verlag, New York.
Van Waerebeek, K., Sequeira, M., Williamson, C., Sanino, G.P., Gallego, P. and Carmo, P. (2006) Live-captures of common bottlenose dolphins Tursiops truncatus and unassessed bycatch in Cuban waters: evidence of sustainability found wanting. Latin American Journal of Aquatic Mammals 5(1): 39-48.

Vieira, J.P., Garcia, A.M. and Grimm, A.M. (2008) Evidences of El Niño effects on the mullet fishery of the Patos Lagoon estuary. Brazilian Archives of Biology and Technology 51(2): 433-440.

Von Ihering, H. (1885) Die Lagoa dos Patos. Deutsche Geographische Blätter 8(2): 164-203.

Williams R., Bain, D.E., Smith, J.C. and Lusseau, D. (2009) Effects of vessels on behaviour patterns of individual southern resident killer whales Orcinus orca. Endangered Species Research 6(3): 199-209.

Yogui, G.T., Santos, M.C.O., Bertozzi, C.P. and Montone, R.C. (2010) Levels of persistent organic pollutants and residual pattern of DDTs in small cetaceans from the coast of São Paulo, Brazil. Marine Pollution Bulletin 60(10): 1862-1867.

Zappes, C.A., Andriolo, A., Simóes-Lopes, P.C. and Di Beneditto, A.P.M. (2011a) 'Human-dolphin (Tursiops truncatus Montagu, 1821) cooperative fishery' and its influence on cast net fishing activities in Barra de Imbé/Tramandaí, Southern Brazil. Ocean \& Coastal Management 54(5): 427-432.

Zappes, C., Gatts, C.E.N., Lodi, L., Andriolo, A. and Di Beneditto, A.P.M. (2011b) Interaçôes entre o golfinho-nariz-degarrafa (Tursiops truncatus) e a pesca artesanal no Arquipélago das Cagarras e áreas adjacentes, Rio de Janeiro, Brasil. Sitientibus série Ciências Biológicas 11(1): 24-30.

Zappes, C., Gatts, C.E.N., Lodi, L.F., Simões-Lopes, P.C., Laporta, P., Andriolo, A. and Di Beneditto, A.P.M. (2014) Comparison of local knowledge about the bottlenose dolphin (Tursiops truncatus Montagu, 1821) in the Southwest Atlantic Ocean: New research needed to develop conservation management strategies. Ocean \& Coastal Management 98(2014): 120-129.

Zerbini, A. and Kotas, J. (1998) A note on cetacean bycatch in pelagic driftnetting off Southern Brazil. Reports of the International Whaling Commission 48: 519-524. Cambridge, England. 